\title{
Prospective development and validation of a liquid immune profile-based signature (LIPS) to predict response of metastatic cancer patients to immune checkpoint inhibitors
}

Jian-Guo Zhou ${ }^{\star 1,2,3}$, Anna-Jasmina Donaubauer ${ }^{\star, 1,2}$, Benjamin Frey ${ }^{1,2}$, Ina Becker $^{1,2}$, Sandra Rutzner ${ }^{1,2}$, Markus Eckstein ${ }^{2,4}$, Roger Sun ${ }^{5,6}, \mathrm{Hu} \mathrm{Ma}^{3}$, Philipp Schubert ${ }^{1,2}$, Claudia Schweizer ${ }^{1,2}$, Rainer Fietkau ${ }^{1,2}$, Eric Deutsch ${ }^{5,6}$, Udo S. Gaipl ${ }^{\#, 1,2,+}$, Markus Hecht ${ }^{\#, 1,2}$

${ }^{1}$ Department of Radiation Oncology, Universitätsklinikum Erlangen, Erlangen, Germany

${ }^{2}$ Comprehensive Cancer Center Erlangen-EMN, Erlangen, Germany

${ }^{3}$ Department of Oncology, The Second Affiliated Hospital of Zunyi Medical University, Zunyi, China

4 Institute of Pathology, Universitätsklinikum Erlangen, Friedrich-Alexander-Universität Erlangen-Nürnberg, Erlangen, Germany 5 Department of Radiation Oncology, Gustave Roussy-CentraleSupélec-TheraPanacea Center of Artificial Intelligence in Radiation Therapy and Oncology, Gustave Roussy, Villejuif, France 6 Université Paris-Saclay, INSERM1030 Radiothérapie Moléculaire,Villejuif France

* JGZ and AJD contributed equally as first authors

\# USG and MH contributed equally as senior authors

E-Mails of the authors:

Jian-Guo Zhou: jianguo.zhou@fau.de

Anna-Jasmina Donaubauer: Anna-Jasmina.Donaubauer@uk-erlangen.de

Benjamin Frey: Benjamin.Frey@uk-erlangen.de

Ina Becker: Ina.Becker@uk-erlangen.de

Sandra Rutzner: sandra.rutzner@uk-erlangen.de

Markus Eckstein: markus.eckstein@uk-erlangen.de 
Roger Sun: ROGER.SUN@gustaveroussy.fr

Hu Ma: mahuab@163.com

Philipp Schubert: Philipp.Schubert@uk-erlangen.de

Claudia Schweizer: Claudia.Schweizer@uk-erlangen.de

Rainer Fietkau: Rainer.Fietkau@uk-erlangen.de

Eric Deutsch: Eric.DEUTSCH@gustaveroussy.fr

Udo S. Gaipl: udo.gaipl@uk-erlangen.de

Markus Hecht: markus.hecht@uk-erlangen.de

+ Corresponding author:

Prof. Dr. Udo S. Gaipl

Department of Radiation Oncology, Universitätsklinikum Erlangen

Friedrich-Alexander-Universität Erlangen-Nürnberg (FAU)

Universitätsstraße 27, 91054 Erlangen, Germany

Tel.: +49 913185 44258; Fax: +49 91318539335

E-mail address: udo.gaipl@uk-erlangen.de. 


\section{Abbreviations}

AUC: The area under the ROC curve

Cl: Confidence interval

C-index: Concordance index

CTLA-4: Cytotoxic T lymphocyte antigen-4

ECOG: Eastern Cooperative Oncology Group

HNSCC: Head and neck squamous cell carcinoma

HR: Hazard ratios

ICI: Immune checkpoint inhibitors

IPT: immunophenotyping

LASSO: Least absolute shrinkage and selection operator

LIPS liquid immune profile-based signature

NE: Not estimate

NK cells: Natural killer cells

NKT cells: Natural killer T cells

NSCLC: Non-small cell lung cancer

OS: Overall survival

PBMCs: Peripheral blood mononuclear cells

PD-1: Programmed cell death protein 1

pDCs: Plasmacytoid Dendritic Cells

PD-L1: Programmed cell death ligand 1

PFS: Progression free survival

RECIST: Response Evaluation Criteria in Solid Tumors

ROC: Receiver operating characteristic

TMB: Tumor mutational burden

Tregs: Regulatory T Cells 
medRxiv preprint doi: https://doi.org/10.1101/2020.08.03.20167163; this version posted October 2, 2020. The copyright holder for this preprint (which was not certified by peer review) is the author/funder, who has granted medRxiv a license to display the preprint in perpetuity.

It is made available under a CC-BY-NC 4.0 International license .

\section{Abstract}

Background: The predictive power of several novel biological markers for treatment response to immune checkpoint inhibitors (ICI) is still not satisfactory for the majority of patients with cancer. It should be the goal to identify easy available blood markers to predict early treatment response to ICI for the clinically highly relevant large number of metastatic cancer patients. The current interim analysis of patients of the ST-ICI cohort therefore focuses on the development and validation of a liquid immune profile-based signature to predict response of metastatic cancer patients to $\mathrm{ICl}$ targeting the programmed cell death protein 1 (PD-1)/PD-L1 axis.

Methods: A total number of 104 patients were prospectively enrolled. 54 immune cell subsets were prospectively analyzed in 89 patients' peripheral blood by multicolor flow cytometry before the second administration of the $\mathrm{ICl}$. Patients were randomly allocated to a training $(n=56)$ and a validation cohort $(n=33)$. Univariate Cox proportional hazards regression analysis and LASSO Cox model were used to create a predictive immune signature.

Results: $89 / 104$ of the cancer patients provided whole blood samples. The identified liquid immune profile-based signature (LIPS) is based on five immune cell subtypes: CD14 ${ }^{\text {high }}$ monocytes, CD8+/PD-1 $1^{+}$Tcells, plasmacytoid dendritic cells (pDCs), neutrophils, and $\mathrm{CD}^{+} 6^{+} / \mathrm{CD} 16^{+}$natural killer (NK)T cells. The signature found achieved a high accuracy (C-index 0.74 vs 0.71 ) for predicting overall survival (OS) benefit in both, the training and validation cohort. In both cohorts, the low-risk group had significantly longer OS than the high-risk group (HR $0.26,95 \% \mathrm{Cl}: 0.12-0.56$, $p=0.00025 ;$ HR $0.30,95 \%$ Cl: $0.10-0.91, p=0.024$, respectively). Regarding the whole cohort, LIPS also predicted progression-free survival (PFS). Clinicopathological features with the exception of brain metastases didn't affect the found LIPS, for both, OS and PFS.

Conclusion: Our study highlights the potential predictive value of LIPS based on easy available blood markers for immunotherapeutic benefit of metastatic cancer patients. 
medRxiv preprint doi: https://doi.org/10.1101/2020.08.03.20167163; this version posted October 2, 2020. The copyright holder for this preprint (which was not certified by peer review) is the author/funder, who has granted medRxiv a license to display the preprint in perpetuity.

It is made available under a CC-BY-NC 4.0 International license.

Keywords: metastatic cancers, immune checkpoint inhibitors, peripheral blood immunophenotyping, predictive immune signature

Trial registration: Prospectively registered in ClinicalTrials.gov (NCT03453892) on January 24, 2018.

\section{Introduction}

Immune checkpoint inhibitors (ICl) can effectively restore the activity of exhausted $\mathrm{CD}^{+}$cytotoxic $\mathrm{T}$ cells and thereby trigger anti-tumor immune responses. During the last years, several ICI were approved for more than ten different tumor entities. However, still only the minority of patients show durable responses. ${ }^{1}$ In clinical trials, the expression of programmed cell death-ligand 1 (PD-L1) on tumor and/or immune cells has been frequently used to select patient subgroups with higher chances of treatment response. However, the predictive power of PD-L1 expression is restricted and its expression varies, as its expression is for example increased after radiotherapy. ${ }^{2-5}$ Consequently, large effort has been made to identify routinely available blood and clinical markers that may predict response to $\mathrm{ICl}$ therapies, ${ }^{6}$ besides and complementary to analyses of genomic instability. ${ }^{7}$ The latter has been assessed via tumor mutational burden $(\mathrm{TMB})^{8}$ or mismatch repair deficiency. ${ }^{9}$ All of these methods have the potential to predict treatment responses to a certain extent, but are still complex to be used in the clinical routine. A further challenge is imaging of the cancer treatment response to $\mathrm{ICI}$. Tumor lesions can initially increase in size due to inflammatory events. ${ }^{10}$ This pseudoprogression cannot easily be distinguished from an increase in size due to tumor growth. Consequently, the classical RECIST 1.1 criterial were modified to the iRECIST criteria, which recommend treatment beyond the first progression. ${ }^{11}$ The main problem of this procedure is that patients with real tumor progression loose time for a probably more efficient radio- and/or chemotherapy.

A recent strategy to complement these approaches is to analyze changes of peripheral blood immune cells at early time points during treatment. ${ }^{12}$ The peripheral blood immune status may have a high predictive power for treatment response of 
medRxiv preprint doi: https://doi.org/10.1101/2020.08.03.20167163; this version posted October 2, 2020. The copyright holder for this preprint (which was not certified by peer review) is the author/funder, who has granted medRxiv a license to display the preprint in perpetuity.

It is made available under a CC-BY-NC 4.0 International license.

solid tumors to $\mathrm{ICl}$, as several immune cells that were already proven to predict treatment responses when being present in the tumor tissue also circulate through the peripheral blood ${ }^{13}$. Furthermore, drawing of peripheral blood can be repeated easily and without an additional risk for the patients compared to repeated biopsies of the tumor tissue. Immunophenotyping of peripheral blood from patients with stage IV melanoma before and after treatment with $\mathrm{ICI}$ already identified pharmacodynamic changes in circulating $\mathrm{CD}^{+} \mathrm{T}$ cells with an exhausted-phenotype. Clinical failure of the patients was identified to be associated with an imbalance between T-cell reinvigoration and tumor burden. ${ }^{14}$ Another study identified a predictive character of proliferating (Ki-67 ${ }^{+}$PD1 ${ }^{+} \mathrm{CD} 8^{+} \mathrm{T}$ cells for response to anti-PD-1 immunotherapy in solid tumors. ${ }^{15}$ Using high-dimensional single-cell mass cytometry, Krieg and colleagues found HLA-DR high expressing monocytes to be of predictive value for responses to anti-PD-1 therapy. ${ }^{16}$

The here introduced preplanned biomarker analysis of the prospective ST-ICl cohort, the peripheral blood immune phenotype of metastasized cancer patients treated with $\mathrm{ICI}$ was prospectively monitored by multi-color flow cytometry. Our aim was to construct a predictive immune signature, based on changes of the peripheral blood immunophenotype that identifies at an early time point of therapy patients who benefit from ICl.

\section{Materials and Methods}

\section{Patients}

Metastatic cancer patients with clinically indicated treatment with $\mathrm{ICl}$ were eligible for this prospective non-interventional study. Patients could be included independent from cancer entity and concomitant radiotherapy. Criteria for eligibility were adult age of at least 18 years and the willingness of the patients to allow regular blood draws for immune phenotyping of peripheral blood. As the trial should represent the predominant clinical situation, there were no limitations regarding baseline Eastern Cooperative Oncology Group (ECOG) performance status or baseline routine blood parameters. Exclusion criteria were fertile patients who refused effective 
medRxiv preprint doi: https://doi.org/10.1101/2020.08.03.20167163; this version posted October 2, 2020. The copyright holder for this preprint (which was not certified by peer review) is the author/funder, who has granted medRxiv a license to display the preprint in perpetuity.

It is made available under a CC-BY-NC 4.0 International license.

contraception during study treatment, persistent drug and/or alcohol abuse, patients not speaking German, patients in legal care and imprisoned patients.

\section{Study design and treatments}

Patients that were treated with $\mathrm{ICI}$ directed against programmed cell death protein 1 (PD-1) or PD-L1 were selected from the ST-ICI cohort (NCT03453892). All ICl were indicated by the treating physician according to current guidelines and clinical standards. The following ICI were used: Nivolumab (Opdivo, Bristol-Myers Squibb, New York City, NY, USA), Pembrolizumab (Keytruda, Merck Sharp \& Dohme, Kenilworth, NJ, USA), Atezolizumab (Tecentriq, Roche Co., Basel, Switzerland), Durvalumab (Imfinzi, AstraZeneca Group plc, Cambridge, England, U.K.), or Avelumab (Bavencio, Pfizer and Merck KGaA, Darmstadt, Germany). Dosing of the $\mathrm{ICI}$ was according to the European Medicines Agency (EMA) marketing authorizations.

The institutional review board at the Friedrich-Alexander-Universität Erlangen-Nürnberg approved the study (number: 2_17 B). The study was performed in accordance with the Declaration of Helsinki. All patients gave written informed consent before enrollment that comprised a data privacy clause for data collection and analysis for research purpose. The research design for the identification of a predictive signature for cancer patients treated with $\mathrm{ICl}$ is displayed in Figure 1A. The redaction of the manuscript followed the STROBE guidelines for observational studies.

\section{Endpoints and assessments}

The primary endpoint of the here presented prospective interim analyses was the association between changes of the patients' peripheral blood immunophenotypes and the clinical outcomes. Main clinical outcome parameters were overall survival (OS), progression-free survival (PFS). OS and PFS were calculated starting with the first administration of the $\mathrm{ICl}$. Peripheral whole blood immune phenotyping was performed before each administration of the $\mathrm{ICl}$. The current analysis focused on the early immune phenotypes, namely before the second administration of the $\mathrm{ICI}$.

\section{Multi-colour flow cytometry}


medRxiv preprint doi: https://doi.org/10.1101/2020.08.03.20167163; this version posted October 2, 2020. The copyright holder for this preprint (which was not certified by peer review) is the author/funder, who has granted medRxiv a license to display the preprint in perpetuity.

It is made available under a CC-BY-NC 4.0 International license .

Whole blood samples of the patients were collected and the fresh whole blood was analyzed by multi-colour flow cytometry according to our previously published and optimized immunophenotyping (IPT) protocols. ${ }^{17} 18$ IPT was performed within three hours after the collection of whole blood. Data acquisition was performed on a Gallios Flow Cytometer (Beckman Coulter) in the standard filter configuration. The Kaluza® Flow Analysis Software (Beckman Coulter) was used for data analysis. The immune cell subpopulations analyzed are visualized and specified in sFigure 1.

\section{Data collection}

Differences in OS and PFS were analysed in dependence of the absolute immune cell counts of each immune cell subset and in dependence of the clinical factors age, gender, tumour entity, PD-L1 expression, and the presence of brain metastases.

\section{Development and validation of liquid immune profile-based signature (LIPS)}

The overall workflow for the development of the LIPS is shown in Figure 1B. Univariate Cox proportional hazard regression was applied to examine the association between peripheral blood immunophenotypes and patients' OS. ${ }^{19}$ Peripheral blood immune cells statistically significant associated $(P<0.2)$ with OS of the patients served as candidates for further analyses. To uncover the practicability and accuracy of LIPS for metastasized cancer patients treated with ICI, all patients were divided randomly into the training (70\%) and validation $(30 \%)$ cohorts. Least absolute shrinkage and selection operator (LASSO) could reduce the complexity of the model and can well be used with the Cox proportional hazard regression model for survival analysis with high dimensional data. ${ }^{20}$ The Cox-LASSO regression model was applied to develop a multi-immunophenotype-based predictive signature for OS in the training cohort. After 200,000-time steps for LASSO, the best c-index related model was selected as LIPS. Subsequently, we analyzed the data in a validation cohort for this model, to assess its feasibility and reliability in patients treated with ICl. The optimal cut off value for the risk score (Figure 2A and D) was determined by surv_cutpoint function in survminer package. All patients were divided into different groups (high-risk or low-risk) based on the cut-off of the risk score, which was calculated by considering the expression of immunophenotypes and the 
medRxiv preprint doi: https://doi.org/10.1101/2020.08.03.20167163; this version posted October 2, 2020. The copyright holder for this preprint (which was not certified by peer review) is the author/funder, who has granted medRxiv a license to display the preprint in perpetuity.

It is made available under a CC-BY-NC 4.0 International license.

correlation coefficient. In order to validate the predictive ability of LIPS for PFS, these same coefficients of LIPS were calculated as risk score for survival analysis.

\section{Statistical analysis}

Associations between clinical characteristics in the training and the validation cohorts were evaluated using the chi-square test. OS time was defined from the date of the first administration of the $\mathrm{ICl}$ to the date of the last follow-up or death of the patient. PFS time was defined from the date of the first administration of the ICI to the date of the last follow-up or first radiological confirmed progression (e.g. imaging date) or date of death (whichever occurs first). The Kaplan-Meier method and Cox proportional hazard regression models were applied to compare survival of the different groups with the immunophenotypes, LIPS and related clinical factors. Univariate, multivariate and subgroup analyses were used to evaluate the impact of other confounding factors. Results of Cox regression analysis are described by means of hazard ratios $(\mathrm{HR}), 95 \% \mathrm{Cl}$ of $\mathrm{HR}$ and $P$ values (Wald test). The concordance index (C-index) and the time-dependent receiver operating characteristic $(\mathrm{ROC})$ curve, and the area under the ROC curve (AUC) values were calculated for different models as a measure of the discriminatory ability that allows comparison of signatures. A signature with a C-index of 0.5 has no predictive value, but the signature with a C-index of 1 would allow a perfect prediction of the patient's outcome. $^{22}$ The C-index was analyzed using the survcomp (version 1.22.0). ${ }^{23}$ The ROC curve and AUC values were calculated with the timeROC package (version 0.3); for survival analyses the survival package was used. All of the analyses were carried out using Rversion 3.6.1 (R Foundation for Statistical Computing) and related packages. $P \leq 0.05$ was considered to be statistically significant.

\section{Results}

\section{Patient characteristics}

A total of 104 patients were prospectively enrolled in the ST-ICI cohort between April 2017 and August 2019 (Figure 1B). Whole blood samples for immunophenotyping before the second $\mathrm{ICl}$ administration were available of 89 patients. The patient characteristics are presented in Table 1. The median age was 65.8 years; $73 \%$ were 
medRxiv preprint doi: https://doi.org/10.1101/2020.08.03.20167163; this version posted October 2, 2020. The copyright holder for this preprint (which was not certified by peer review) is the author/funder, who has granted medRxiv a license to display the preprint in perpetuity.

It is made available under a CC-BY-NC 4.0 International license .

male. Most frequent tumor entities were head and neck squamous cell carcinoma (HNSCC) in 40 patients (45\%) and non-small cell lung cancer (NSCLC) in 39 patients (44\%). The used drugs were Nivolumab in 58 patients (65\%), Pembrolizumab in 20 patients (23\%), Durvalumab in 8 patients (9\%), Avelumab in 2 patients $(2 \%)$, Atezolizumab in 1 patient (1\%).

The ICI was first line treatment in 19 patients (21\%). In the recurrent and/or metastatic setting, 13 patients (15\%) had received one prior systemic treatment and 57 patients (64\%) two or more prior systemic treatments. The median follow up was 8.3 months. A total of 57 OS-events and 72 PFS-events occurred during the follow up period. Median OS was 8.7 months, median PFS was 4.2 months.

\section{Development and definition of the LIPS}

After the data cleaning steps, 54 peripheral blood immune markers were included into an univariate cox survival analysis. The following 14 of them were associated with OS $(P<0.2)$ : monocytes $\left(\mathrm{CD} 14^{\text {high }}\right)$, monocytes (CD14 $\left.{ }^{\text {low }}\right)$, neutrophils, dendritic cells (DCs), myeloid (m)DCs-1, mDCs-2, plasmacytoid DCs (pDCs), natural killer (NK) cells $\left(\mathrm{CD} 56^{\text {high }} / \mathrm{CD} 16^{+}\right)$, NKT cells $\left(\mathrm{CD}^{+} / \mathrm{CD} 16^{+}\right)$, NKT cells $\left(\mathrm{CD} 16^{+}\right), \mathrm{CD} 8+\mathrm{T}$ cells $\left(\mathrm{PD}-1^{+}\right), \mathrm{CD}^{+} \mathrm{T}$ cells $\left(\mathrm{CD} 25^{+}\right), \mathrm{CD}^{+} \mathrm{T}$ cells $\left(\mathrm{CD} 69^{+}\right)$, and regulatory $\mathrm{T}$ cells (Tregs)

(Table 2).

The ST-ICl cohort was then randomly assigned to a training cohort $(n=56)$ and a validation cohort $(n=33)$ for further LASSO proportional hazards Cox regression analysis. After 200,000 times repeat LASSO regression, the highest C-index's model was chosen as the LIPS. This predictive signature model obtained from the training cohort showed the following risk score $=(0.00001219963 \times$ the absolute immune cell counts of neutrophils $)+(-0.0335468 \times$ the absolute immune cell counts of pDCs $)+$ $\left(-0.08766993 \times\right.$ the absolute immune cell counts of NKT cells $\left.\left(\mathrm{CD}^{2} 6^{+} / \mathrm{CD}^{+} 6^{+}\right)\right)$ $+\left(-0.01120408 \times\right.$ the absolute immune cell counts of monocytes $\left(\right.$ CD14 $\left.\left.4^{\text {high }}\right)\right)+$ $\left(0.004149556 \times\right.$ the absolute immune cell counts of $\mathrm{CD} 8^{+} \mathrm{T}$ cells $\left.\left(\mathrm{PD}-1^{+}\right)\right)$. In this signature, neutrophils and $\mathrm{CD}^{+} \mathrm{T}$ cells being positive for PD-1 surface expression were positive coefficients, which means that patients with increasing absolute counts had a shorter OS. However, pDCs, NKT cells $\left(\mathrm{CD} 56^{+} / \mathrm{CD} 16^{+}\right)$and monocytes 
medRxiv preprint doi: https://doi.org/10.1101/2020.08.03.20167163; this version posted October 2, 2020. The copyright holder for this preprint (which was not certified by peer review) is the author/funder, who has granted medRxiv a license to display the preprint in perpetuity.

It is made available under a CC-BY-NC 4.0 International license .

$\left(C D 14^{\text {high }}\right)$ were negative coefficients, which means that patients with increasing absolute cell counts had a longer OS.

According to best C-index $(0.74,96 \% \mathrm{Cl} 0.67-0.82)$, the optimal cut-off is -0.487 , which classified the training cohort into a low- risk group $(n=44)$ and a high-risk group $(\mathrm{n}=12)$ (Figure 2 A-C).

In the training cohort, each unit increase in LIPS was associated with a 0.26 fold increase in OS rates $(95 \% \mathrm{Cl}: 0.12-0.56, \mathrm{P}=0.00025)$. Median OS in the LIPS lowand high-risk groups was 14.5 (95\% Cl: 10.1-NE (not estimable)) vs 5.4 (95\% Cl: 3.0-NE) months, respectively (Figure 3A).

The validation cohort was classified using the same cut-off of LIPS into a low-risk group ( $n=29)$ and a high-risk group $(n=4)$ (Figure 2D-F). The validation cohort confirmed the proposed risk model (C-index $=0.71,95 \% \mathrm{Cl}: 0.62-0.81)$. The median OS in the low- and high-risk groups was 11.5 (95\% Cl: 9.2- 20.6) vs 3.7 (95\% Cl: 2.8$\mathrm{NE})$ months (HR=0.30, 95\% Cl: $0.10-0.91, P=0.024)$, respectively (Figure $3 \mathrm{C}$ ).

The sensitivity and specificity of LIPS for predicting the OS were plotted in a time-dependent ROC. In the training cohort, the AUC values for 6-, 12- and 24-month OS prediction were $0.811,0.708$ and 0.788 respectively (Figure $3 \mathbf{B}$ ). In the validation cohort, the AUC values for 6-, 12- and 24-month OS prediction were $0.731,0.716$ and 0.768, respectively (Figure 3D).

In the total ST-ICI cohort, median OS in the low- and high-risk groups was 12.5 (95\% Cl: 9.8-19.7) vs 4.7 (95\% Cl: 3.0- NE) months (HR=0.28, 95\% Cl: 0.15-0.52, $\mathrm{P}<0.001$ ), respectively (Figure 4A). The time-ROC results indicate that this signature is still a powerful predictor for OS in the whole cohort $\left(\mathrm{AUC}_{6 \mathrm{~m}}=0.77, \mathrm{AUC}_{12 \mathrm{~m}}=0.72\right.$, $\left.\mathrm{AUC}_{24 \mathrm{~m}}=0.82\right)$ (Figure 4B).

Additionally, LIPS also can predict progression-free survival benefit for patients treated with $\mathrm{ICI}$ (low-risk vs high-risk: $\mathrm{HR}=0.22$ [95\% $\mathrm{Cl}$ 0.12-0.39]; the median PFS of low risk and high risk are 6.3 and 2.0 months, respectively (Figure $4 \mathrm{C}$ ); $\mathrm{AUC}_{6 \mathrm{~m}}=0.69$, $A U C_{12 m}=0.68, A U C_{24 m}=0.69$ (Figure 4D). These results indicate that the developed LIPS can predict which cancer patients have prolonged OS and PFS after treatment with anti-PD-1 or anti-PD-L1 in the early phase. 
medRxiv preprint doi: https://doi.org/10.1101/2020.08.03.20167163; this version posted October 2, 2020. The copyright holder for this preprint (which was not certified by peer review) is the author/funder, who has granted medRxiv a license to display the preprint in perpetuity.

It is made available under a CC-BY-NC 4.0 International license.

\section{Predictive role of LIPS in metastatic cancer patients treated with ICI}

To determine whether the LIPS could serve as an independent predictive factor, Cox proportional hazard regression model was used for the detection of the relationships between OS and the clinical factors (Table 3). In the ST-ICI cohort, univariate analysis showed that LIPS and brain metastasis were significantly associated with OS, while multivariate analysis showed that age, PD-L1 expression 50-100\% and LIPBS significantly associated with OS $(P<0.05)$.

Furthermore, LIPS and PD-L1 expression 1-49\% were significantly associated with PFS in univariate and multivariate analysis. These results indicate that LIPS remained an independent survival benefit predictor for metastatic cancer patients treated with ICl.

\section{Applicability of LIPS in cancer patients with different clinical characteristics}

Post-hoc subgroup analyses based on patient characteristics suggested that OS and PFS hazard ratios favoured the LIPS low risk group in most subgroups (Figure 5, sFigures 2-6). Regarding OS, the subgroup analyses by PD-L1 expression suggested that median OS tended to be longer in patients with PD-L1 expression $<1 \%$ in the low-risk group $(\mathrm{HR}=0.45(95 \% \mathrm{Cl} 0.16-1.24), 9.1$ months $[95 \% \mathrm{Cl} 4.5-21]$ vs 5.0 months [3.0-NE]; Figure 5A, sFigure 3). However, no differences of OS and PFS were found between low-risk and high-risk groups in patients with brain metastasis (sFigure 4). Median OS and PFS of patients stratified by tumour entity, age, and gender are shown in the sFigures 2, 5, and 6, respectively.

\section{Discussion}

In recent years, $\mathrm{ICI}$ with or without chemotherapy were approved for multiple recurrent or metastatic cancer types. However, a maximum of $20 \%$ of non-selected patients experience long-term benefit. ${ }^{24}$ Numerous studies suggest that TMB may predict clinical response to $\mathrm{ICI}$ across multiple cancer types. ${ }^{25-27}$ However, different studies used different cut-off values based on independently companies' database or cancer types to define low and high TMB.

The detection of PD-L1 by different methods or cut-off values could also guide anti-PD-1/PD-L1 therapy, but still harbours the risk of a false-negative patient 
medRxiv preprint doi: https://doi.org/10.1101/2020.08.03.20167163; this version posted October 2, 2020. The copyright holder for this preprint (which was not certified by peer review) is the author/funder, who has granted medRxiv a license to display the preprint in perpetuity.

It is made available under a CC-BY-NC 4.0 International license .

stratification. ${ }^{28-30}$ The gene methylation status may also serve to select patients who will experience clinical benefit from PD-1 blockade. ${ }^{31}$ Nevertheless, there is still particular need of additional or complementary timesaving, cost-effective, safe and easy applicable tools to identify cancer patients who should benefit from ICI.

In this context, a detailed knowledge about the immune status, both in the tumor and in the periphery, is needed to judge about the potential of cancer immunotherapy and the efficacies of immunotherapies. ${ }^{32}$ Tumor immunogenicity scores are under evaluation as predictors for responses to $\mathrm{ICl}^{33}$ Previous studies already indicated peripheral blood immune cell subsets like PD $-1^{+} \mathrm{CD}_{56}{ }^{+} \mathrm{T}_{\text {cells }}{ }^{34}$ or CD4+ and CD8+ cells ${ }^{35}$ to be associated with favourable outcome for advanced melanoma patients treated with ipilimumab directed against cytotoxic $T$ lymphocyte antigen-4 (CTLA-4). Now we identified a liquid immune profile-based signature to early predict response of metastatic cancer patients to anti-PD-1/PD-L1 treatment.

To our best knowledge, the prospective ST-ICI cohort is the first one, which prospectively included a whole-blood multicolor flow cytometry-based approach for identification of a detailed peripheral immune status in a clinical relevant multi-type advanced cancer patient cohort treated with anti-PD-1/PD-L1 ICI. To avoid large volume blood sampling for preparation of peripheral blood mononuclear cells (PBMC) and to not exclude granulocytes from the analyses, the IPT was performed in fresh whole blood without preceding isolation of specific cells. Thus, whole blood assays gain importance in easy screening of large number of blood parameters. Within the ST-ICI cohort, 54 immune cell subsets were monitored in the patients with the need of less than $1 \mathrm{ml}$ of peripheral whole blood. Our identified LIPS has the advantage of being easily integrated into clinical use for nominal expense. In a first step, 14 immune cell subsets were identified to be associated with OS. Furthermore, LASSO regression constructed the LIPS signature including neutrophils, pDCs, NKT cells $\left(\mathrm{CD} 56^{+} / \mathrm{CD} 16^{+}\right)$, monocytes $\left(\mathrm{CD} 14^{\text {high }}\right)$ and $\mathrm{CD} 8^{+} \mathrm{T}$ cells $\left(\mathrm{PD}-1^{+}\right)$. This signature includes innate and adaptive immune cells and serves as an effective tool for the identification of metastatic cancer patients who benefit from $\mathrm{ICl}$ treatment. It is becoming more and more evident that multiple immune cell subsets in a concerted 
medRxiv preprint doi: https://doi.org/10.1101/2020.08.03.20167163; this version posted October 2, 2020. The copyright holder for this preprint (which was not certified by peer review) is the author/funder, who has granted medRxiv a license to display the preprint in perpetuity.

It is made available under a CC-BY-NC 4.0 International license.

action may help for selecting patients that are likely to respond to $\mathrm{ICI}^{36}$

We identified that increasing amounts of neutrophils in the peripheral blood of cancer patients were associated with less benefit from ICI treatment. Neutrophils have been reported to support for example the development of metastasis through multiple mechanisms, such as the release of proteases that degrade antitumor factors, and leukotrienes that propagate metastasis-initiating cells. In addition, pro-tumorigenic neutrophils suppress antitumor T cell responses. ${ }^{37}$ Decreased migration of neutrophils to tumor areas or the inhibition of granulocyte colony stimulating factor to decrease the amount of neutrophils has already shown efficacy in preclinical models. ${ }^{38}$ Recent findings suggests that neutrophil antagonism will improve the efficacy of $\mathrm{ICl}$ therapy in the future. ${ }^{12}$

Regarding innate immune cells not of the granulocytic, but of the monocytic compartment, increased amounts of CD14 high expressing monocytes in the peripheral blood are associated with improved prognosis. This is in accordance with the findings of Krieg et al who identified CD14 $/ / H L A-D R^{+}$monocytes as a strong predictor of PFS and OS in response to anti-PD-1 immunotherapy in melanoma patients. ${ }^{39}$ We here show the importance of CD14 high expressing monocytes in the peripheral blood for non-melanoma solid tumour patients.

Further, we found that increased amounts of plasmacytoid dendritic cells (pDCs) are beneficial for the PFS and OS. pDCs have a central role in activating host innate and adaptive immune responses and they are known as the major IFN type I-producing cells. Thereby, pDCs activate many other cell types, such as monocytes, NK cells, and $\mathrm{T}$ cells which are known to be also central for anti-tumor immune responses. ${ }^{40}$ High levels of circulating pDCs were already found to be predict a favorable outcome in patients with breast cancer ${ }^{41}$ and for patients with pancreatic adenocarcinoma. ${ }^{42}$ NKT cells are suggested to induce a cross talk of pDCs with conventional DCs that result in induction of memory CD8+ T cells. ${ }^{43}$ We identified increased numbers of NKT cells in patients of the ST-ICI cohort to be favorable for PFS and OS. Just recently, it was shown for patients with NSCLC that increased amounts of peripheral NK cells correlate with responses to anti-PD-1 treatment. ${ }^{44}$ The role for NKT cells in this 
medRxiv preprint doi: https://doi.org/10.1101/2020.08.03.20167163; this version posted October 2, 2020. The copyright holder for this preprint (which was not certified by peer review) is the author/funder, who has granted medRxiv a license to display the preprint in perpetuity.

It is made available under a CC-BY-NC 4.0 International license.

scenario has not been investigated before, but it is becoming more and more evident that NKT cells are important in anti-tumor immunity as they e.g. reinvigorate exhausted immune cells in the tumor microenvironment. ${ }^{45}$

Exhausted immune cells fail to contribute to anti-tumor immunity. Increased numbers of PD-L1 $1^{+}$NK cells in the peripheral blood, e.g., are associated with poor response to anti-PD-1 treatment of patients with NSCLC. ${ }^{46}$ However, intratumoral $\mathrm{CD}^{+} \mathrm{T}$ cells which are positive for PD-1+ were shown to be predictive for response and survival upon anti-PD-1 antibody therapy, as shown in a small cohort of patients with NSCLC. ${ }^{47}$ Studies in chronic myeloid leukemia patients just recently revealed that differences in PD-1 Expression on $\mathrm{CD}^{+}{ }^{+}$-cells might predict the disease course. ${ }^{48}$ Our immune monitoring suggests that increased amounts of circulating PD $-1^{+} \mathrm{CD} 8^{+} \mathrm{T}$ cells at early time points of ICI therapy predict a poorer OS and PFS in patients with metastatic solid tumors treated with $\mathrm{ICl}$. This might indicate that in these cases the activated $C D 8^{+} \mathrm{T}$ cells cannot enter properly into the tumor and exert their anti-tumor activity.

The ST-ICI cohort composes a clinically highly relevant group of advanced stage patients with solid tumors, what includes some confounding factors like treatment with different ICI, different tumor types, brain metastasis, and PD-L1 expression. However, the multivariable Cox regression and subgroup analyses suggests that LIPS is an independent prognostic factor for advanced cancer patients treated with $\mathrm{ICI}$ targeting the PD-1/PD-L1 axis. Subgroup analysis suggest that this immune signature can stably predict OS and PFS benefit for cancer patients treated with $\mathrm{ICl}$ in any subgroups, except for brain metastasis. Although patients with brain metastases can benefit from $\mathrm{ICl}$ treatment ${ }^{49}$ the knowledge about the immune microenvironment at this tumor location side is scarce ${ }^{50} 51$ and future trials will have to particularly focus on this subgroup of the ST-ICI study population. In present clinical practices, PD-L1 expression is an essential biomarker as drug approvals mostly depend on its expression. However, our subgroup analyses revealed that the LIPS predicts survival benefits independent from the PD-L1 expression status. Notably, LIPS identified more 
than $82 \%$ of all advanced cancer patients, who benefit from anti-PD-1/PD-L1 antibodies.

\section{Conclusion}

Our prospective analyses of the immune status of patients of the ST-ICl cohort demonstrated that LIPS could predict at a very early time point of immune therapy which cancer patients with advanced disease will benefit from $\mathrm{ICl}$ treatment and therefore could guide clinical decisions in the future. This newly identified LIPS is a low-cost, safe, easy and broadly applicable and effective early predictor for OS and PFS in metastatic cancer patients treated with ICI.

\section{Availability of data and materials}

The datasets used and/or analyzed during the current study are available from the corresponding author on reasonable request.

\section{Acknowledgements}

The authors thank the patients who participated in the study, their supporters, the investigators, and clinical research staff from the Department of Radiation Oncology. The present work was performed by Jian-Guo Zhou in (partial) fulfilment of the requirements for containing the degree "Dr. rer. biol. hum".

\section{Funding}

There was no external funding for this trial. The study was supported by the Department of Radiation Oncology, Universitätsklinikum Erlangen, Friedrich-Alexander-Universität Erlangen-Nürnberg, Erlangen, Germany and it was partly supported by the BMBF (GREWIS-alpha, 02NUK050E).

\section{Contributions}

Conception and design: MH, USG, BF, RF, HM, JGZ, ME, AD

Development of methodology: JGZ, AD

Acquisition of data: $\mathrm{AD}, \mathrm{SR}, \mathrm{IB}, \mathrm{BF}, \mathrm{ME}, \mathrm{MH}, \mathrm{USG}$ 
medRxiv preprint doi: https://doi.org/10.1101/2020.08.03.20167163; this version posted October 2, 2020. The copyright holder for this preprint (which was not certified by peer review) is the author/funder, who has granted medRxiv a license to display the preprint in perpetuity.

It is made available under a CC-BY-NC 4.0 International license .

Analysis and interpretation of data: JGZ, AD, ED, RS, PS, USG, MH

Writing, review, and/or revision of the manuscript: JGZ, AD, RF, MH, USG, ED, RS, CS, PS

Administrative, technical, or material support: SR, CS, MH

Study supervision: USG, MH, RF, BF

\section{Ethics approval and consent to participate}

The protocol, any amendments, and informed consent forms were approved by the institutional review boards/independent ethics committees (number: 2_17 B). The study was performed in accordance with the Declaration of Helsinki. All patients gave written informed consent before enrolment that comprised a data privacy clause for data collection and analysis for research purpose.

\section{Competing interests}

$\mathrm{MH}$ reports conflict of interest with Merck Serono (advisory boards, honoraria for lectures, travel grants, research funding); MSD (advisory boards, travel grants, research funding); AstraZeneca (research funding); Novartis (research funding); BMS (advisory boards, honoraria for lectures); Teva (travel grants). USG received support for presentation activities for Dr. Sennewald Medizintechnik $\mathrm{GmbH}$, has received support for investigator initiated clinical studies (IITs) from MSD and AstraZeneca and contributed at Advisory Boards Meetings of AstraZeneca and Bristol-Myers Squibb. JGZ received support from AstraZeneca (travel grants). HM reports conflict of interest with Merck Serono (advisory boards, honoraria for lectures, travel grants); MSD (advisory boards, honoraria for lectures, travel grants); AstraZeneca (advisory boards, honoraria for lectures, travel grants); BMS (advisory boards, honoraria for lectures, travel grants). RS received travel and accommodation expenses from AstraZeneca. ED reports grants and honoraria from ROCHE GENENTECH, grants from SERVIER, grants and honoraria from ASTRAZENECA, MERCK SERONO, BMS and MSD, outside the submitted work. SR conflict of interest with AstraZeneca (research funding); MSD (research funding). ME conflict of interest with Diaceutics (employment, 
honoraria, advisory role, speakers' bureau, travel expenses); AstraZeneca (honoraria, advisory role, speakers' bureau, travel expenses); Roche (honoraria, travel expenses); MSD (honoraria, speakers' bureau); GenomicHealth (honoraria, advisory role, speakers bureau, travel expenses); Astellas (honoraria, speakers' bureau); Janssen-Cilag (honoraria, advisory role, research funding, travel expenses); Stratifyer (research funding, patents). RF conflict of interest with MSD (honoraria, advisory role, research funding, travel expenses); Fresenius (honoraria); BrainLab (honoraria); AstraZeneca (honoraria, advisory role, research funding, travel expenses); Merck Serono (advisory role, research funding, travel expenses); Novocure (advisory role, speakers' bureau, research funding); Sennewald (speakers' bureau, travel expenses). 


\section{References}

1. Das S, Johnson DB. Immune-related adverse events and anti-tumor efficacy of immune checkpoint inhibitors. Journal for ImmunoTherapy of Cancer 2019;7(1):306. doi: 10.1186/s40425-019-0805-8

2. Burtness B, Harrington KJ, Greil R, et al. KEYNOTE-048: Phase III study of first-line pembrolizumab $(P)$ for recurrent/metastatic head and neck squamous cell carcinoma (R/M HNSCC). Annals of Oncology 2018;29 (suppl_8)

3. Mok TSK, Wu YL, Kudaba I, et al. Pembrolizumab versus chemotherapy for previously untreated, PD-L1-expressing, locally advanced or metastatic non-small-cell lung cancer (KEYNOTE-042): a randomised, open-label, controlled, phase 3 trial. Lancet 2019;393(10183):1819-30. doi: 10.1016/S0140-6736(18)32409-7 [published Online First: 2019/04/09]

4. Derer A, Spiljar M, Bäumler M, et al. Chemoradiation Increases PD-L1 Expression in Certain Melanoma and Glioblastoma Cells. Front Immunol 2016; 7

5. Hecht M, Buttner-Herold M, Erlenbach-Wunsch K, et al. PD-L1 is upregulated by radiochemotherapy in rectal adenocarcinoma patients and associated with a favourable prognosis. European journal of cancer 2016;65:52-60. doi: 10.1016/j.ejca.2016.06.015

6. Hopkins AM, Rowland A, Kichenadasse G, et al. Predicting response and toxicity to immune checkpoint inhibitors using routinely available blood and clinical markers. $\mathrm{Br} J$ Cancer 2017;117(7):913-20. doi: 10.1038/bjc.2017.274 [published Online First: 2017/09/28]

7. Zaretsky JM, Garcia-Diaz A, Shin DS, et al. Mutations Associated with Acquired Resistance to PD-1 Blockade in Melanoma. N Engl J Med 2016;375(9):819-29. doi: 10.1056/NEJMoa1604958 [published Online First: 2016/07/20]

8. Vokes NI, Liu D, Ricciuti B, et al. Harmonization of Tumor Mutational Burden Quantification and Association With Response to Immune Checkpoint Blockade in Non-Small-Cell Lung Cancer. JCO Precis Oncol 2019;3 doi: 10.1200/PO.19.00171 [published Online First: 2019/12/14]

9. Le DT, Uram JN, Wang H, et al. PD-1 Blockade in Tumors with Mismatch-Repair Deficiency. $\quad N$ Engl J Med 2015;372(26):2509-20. doi: 10.1056/NEJMoa1500596

10. Chai LF, Prince E, Pillarisetty VG, et al. Challenges in assessing solid tumor responses to immunotherapy. Cancer Gene Ther 2019 doi: 10.1038/s41417-019-0155-1 [published Online First: 2019/12/12]

11. Seymour L, Bogaerts J, Perrone A, et al. iRECIST: guidelines for response criteria for use in trials testing immunotherapeutics. Lancet Oncol 2017;18(3):e143-e52. doi: 10.1016/S1470-2045(17)30074-8

12. Zhang $\mathrm{H}$, Houghton AM. Good cops turn bad: The contribution of neutrophils to immune-checkpoint inhibitor treatment failures in cancer. Pharmacology \& therapeutics 2020:107662. doi: 10.1016/j.pharmthera.2020.107662 [published Online First: 2020/08/18] 
medRxiv preprint doi: https://doi.org/10.1101/2020.08.03.20167163; this version posted October 2, 2020. The copyright holder for this preprint (which was not certified by peer review) is the author/funder, who has granted medRxiv a license to display the preprint in perpetuity.

It is made available under a CC-BY-NC 4.0 International license .

13. Chen JA, Ma W, Yuan J, et al. Translational Biomarkers and Rationale Strategies to Overcome Resistance to Immune Checkpoint Inhibitors in Solid Tumors. Cancer treatment and research 2020;180:251-79. doi: 10.1007/978-3-030-38862-1_9 [published Online First: 2020/03/28]

14. Huang AC, Postow MA, Orlowski RJ, et al. T-cell invigoration to tumour burden ratio associated with anti-PD-1 response. Nature 2017;545(7652):60-65. doi: 10.1038/nature22079 [published Online First: 2017/04/12]

15. Kim KH, Cho J, Ku BM, et al. The First-week Proliferative Response of Peripheral Blood PD-1(+)CD8(+) T Cells Predicts the Response to Anti-PD-1 Therapy in Solid Tumors. Clin Cancer Res 2019;25(7):2144-54. doi: 10.1158/1078-0432.CCR-18-1449 [published Online First: 2019/01/17]

16. Krieg $C$, Nowicka M, Guglietta $S$, et al. High-dimensional single-cell analysis predicts response to anti-PD-1 immunotherapy. Nat Med 2018;24(2):144-53. doi: 10.1038/nm.4466 [published Online First: 2018/01/09]

17. Rühle PF, Fietkau R, Gaipl US, et al. Development of a Modular Assay for Detailed Immunophenotyping of Peripheral Human Whole Blood Samples by Multicolor Flow Cytometry. Int $J$ Mol Sci 2016;17(8):1316. doi: 10.3390/ijms 17081316

18. Donaubauer A-J, Rühle PF, Becker I, et al. One-Tube Multicolor Flow Cytometry Assay (OTMA) for Comprehensive Immunophenotyping of Peripheral Blood. In: Steinitz M, ed. Human Monoclonal Antibodies: Methods and Protocols. New York, NY: Springer New York 2019:189-212.

19. Simon N, Friedman J, Hastie T, et al. Regularization Paths for Cox's Proportional Hazards Model via Coordinate Descent. J Stat Softw 2011;39(5):1-13. doi: 10.18637/jss.v039.i05

20. Zhou J-G, Zhao H-T, Jin S-H, et al. Identification of a RNA-seq-based signature to improve prognostics for uterine sarcoma. Gynecologic Oncology 2019;155(3):499-507. doi: https://doi.org/10.1016/j.ygyno.2019.08.033

21. Zhou J-G, Liang B, Jin S-H, et al. Development and Validation of an RNA-Seq-Based Prognostic Signature in Neuroblastoma. Frontiers in Oncology 2019;9(1361) doi: 10.3389/fonc.2019.01361

22. Brentnall AR, Cuzick J. Use of the concordance index for predictors of censored survival data. Stat Methods Med Res 2018;27(8):2359-73. doi: 10.1177/0962280216680245 [published Online First: 2016/12/29]

23. Haibe-Kains B, Desmedt C, Sotiriou C, et al. A comparative study of survival models for breast cancer prognostication based on microarray data: does a single gene beat them all? Bioinformatics 2008;24(19):2200-08. doi: 10.1093/bioinformatics/btn374 [published Online First: 2008/07/17]

24. Herbst RS, Baas P, Kim DW, et al. Pembrolizumab versus docetaxel for previously treated, PD-L1-positive, advanced non-small-cell lung cancer (KEYNOTE-010): a randomised controlled trial. Lancet 2016;387(10027):1540-50. doi: 10.1016/S0140-6736(15)01281-7

25. Wang Z, Duan J, Cai S, et al. Assessment of Blood Tumor Mutational Burden as a Potential Biomarker for Immunotherapy in Patients With Non-Small Cell Lung 
medRxiv preprint doi: https://doi.org/10.1101/2020.08.03.20167163; this version posted October 2, 2020. The copyright holder for this preprint (which was not certified by peer review) is the author/funder, who has granted medRxiv a license to display the preprint in perpetuity. It is made available under a CC-BY-NC 4.0 International license .

Cancer With Use of a Next-Generation Sequencing Cancer Gene Panel. JAMA oncology 2019;5(5):696-702. doi: 10.1001/jamaoncol.2018.7098

26. Samstein RM, Lee $\mathrm{C}-\mathrm{H}$, Shoushtari AN, et al. Tumor mutational load predicts survival after immunotherapy across multiple cancer types. Nature Genetics 2019;51(2):202-06. doi: 10.1038/s41588-018-0312-8

27. Hellmann MD, Nathanson T, Rizvi H, et al. Genomic Features of Response to Combination Immunotherapy in Patients with Advanced Non-Small-Cell Lung Cancer. Cancer Cell 2018;33(5):843-52.e4. doi: https://doi.org/10.1016/j.ccell.2018.03.018

28. Takada K, Toyokawa G, Okamoto T, et al. A Comprehensive Analysis of Programmed Cell Death Ligand-1 Expression With the Clone SP142 Antibody in Non-Small-Cell Lung Cancer Patients. Clin Lung Cancer 2017;18(5):572-82 e1. doi: 10.1016/j.cllc.2017.02.004 [published Online First: 2017/03/21]

29. Lee HH, Wang YN, Xia W, et al. Removal of N-Linked Glycosylation Enhances PD-L1 Detection and Predicts Anti-PD-1/PD-L1 Therapeutic Efficacy. Cancer Cell 2019;36(2):168-78 e4. doi: 10.1016/j.ccell.2019.06.008 [published Online First: 2019/07/23]

30. Okuma Y, Wakui H, Utsumi H, et al. Soluble Programmed Cell Death Ligand 1 as a Novel Biomarker for Nivolumab Therapy for Non-Small-cell Lung Cancer. Clin Lung Cancer 2018;19(5):410-17 e1. doi: 10.1016/j.cllc.2018.04.014 [published Online First: 2018/06/04]

31. Duruisseaux M, Martinez-Cardus A, Calleja-Cervantes ME, et al. Epigenetic prediction of response to anti-PD-1 treatment in non-small-cell lung cancer: a multicentre, retrospective analysis. Lancet Respir Med 2018;6(10):771-81. doi: 10.1016/S2213-2600(18)30284-4 [published Online First: 2018/08/14]

32. Gnjatic S, Bronte V, Brunet LR, et al. Identifying baseline immune-related biomarkers to predict clinical outcome of immunotherapy. $J$ Immunother Cancer 2017;5:44. doi: 10.1186/s40425-017-0243-4 [published Online First: 2017/05/19]

33. Wang $S$, He Z, Wang $X$, et al. Antigen presentation and tumor immunogenicity in cancer immunotherapy response prediction. Elife 2019;8 doi: 10.7554/eLife.49020 [published Online First: 2019/11/27]

34. Bochem J, Zelba H, Amaral T, et al. Peripheral PD-1+CD56+ T-cell frequencies correlate with outcome in stage IV melanoma under PD-1 blockade. PLoS One 2019;14(8):e0221301. doi: 10.1371/journal.pone.0221301 [published Online First: 2019/08/17]

35. Martens A, Wistuba-Hamprecht $\mathrm{K}$, Yuan J, et al. Increases in Absolute Lymphocytes and Circulating CD4+ and CD8+ T Cells Are Associated with Positive Clinical Outcome of Melanoma Patients Treated with Ipilimumab. Clinical Cancer Research 2016;22(19):4848-58. doi: 10.1158/1078-0432.Ccr-16-0249

36. Petitprez F, Meylan M, de Reyniès A, et al. The Tumor Microenvironment in the Response to Immune Checkpoint Blockade Therapies. Front Immunol 2020;11:784. doi: 10.3389/fimmu.2020.00784 [published Online First: 
medRxiv preprint doi: https://doi.org/10.1101/2020.08.03.20167163; this version posted October 2, 2020. The copyright holder for this preprint (which was not certified by peer review) is the author/funder, who has granted medRxiv a license to display the preprint in perpetuity.

It is made available under a CC-BY-NC 4.0 International license .

2020/05/28]

37. Tüting $\mathrm{T}$, Visser KEd. How neutrophils promote metastasis. Science 2016;352(6282):145-46. doi: 10.1126/science.aaf7300

38. Ocana A, Nieto-Jiménez C, Pandiella A, et al. Neutrophils in cancer: prognostic role and therapeutic strategies. Molecular Cancer 2017;16(1):137. doi: 10.1186/s12943-017-0707-7

39. Krieg C, Nowicka M, Guglietta S, et al. High-dimensional single-cell analysis predicts response to anti-PD-1 immunotherapy. Nature Medicine 2018;24(2):144-53. doi: 10.1038/nm.4466

40. Koucký V, Bouček J, Fialová A. Immunology of Plasmacytoid Dendritic Cells in Solid Tumors: A Brief Review. Cancers (Basel) 2019;11(4):470. doi: 10.3390/cancers 11040470

41. Kini Bailur J, Gueckel B, Pawelec G. Prognostic impact of high levels of circulating plasmacytoid dendritic cells in breast cancer. Journal of Translational Medicine 2016;14(1):151. doi: 10.1186/s12967-016-0905-x

42. Tjomsland V, Sandström $P$, Spångeus $A$, et al. Pancreatic adenocarcinoma exerts systemic effects on the peripheral blood myeloid and plasmacytoid dendritic cells: an indicator of disease severity? BMC Cancer 2010;10(1):87. doi: 10.1186/1471-2407-10-87

43. Shimizu K, Asakura M, Shinga J, et al. Invariant NKT cells induce plasmacytoid dendritic cell (DC) cross-talk with conventional DCs for efficient memory CD8+ $\mathrm{T}$ cell induction. $J$ Immunol 2013;190(11):5609-19. doi: 10.4049/jimmunol.1300033

44. Youn JI, Park SM, Park S, et al. Peripheral natural killer cells and myeloid-derived suppressor cells correlate with anti-PD-1 responses in non-small cell lung cancer. Scientific reports 2020;10(1):9050. doi: 10.1038/s41598-020-65666-X [published Online First: 2020/06/05]

45. Bae EA, Seo H, Kim IK, et al. Roles of NKT cells in cancer immunotherapy. Archives of pharmacal research 2019;42(7):543-48. doi: 10.1007/s12272-019-01139-8 [published Online First: 2019/03/13]

46. Juliá EP, Mandó P, Rizzo MM, et al. Peripheral changes in immune cell populations and soluble mediators after anti-PD-1 therapy in non-small cell lung cancer and renal cell carcinoma patients. Cancer immunology, immunotherapy : Cll 2019;68(10):1585-96. doi: 10.1007/s00262-019-02391-z [published Online First: 2019/09/14]

47. Thommen DS, Koelzer $\mathrm{VH}$, Herzig $\mathrm{P}$, et al. A transcriptionally and functionally distinct PD-1(+) CD8(+) T cell pool with predictive potential in non-small-cell lung cancer treated with PD-1 blockade. Nat Med 2018;24(7):994-1004. doi: 10.1038/s41591-018-0057-z [published Online First: 2018/06/13]

48. Lee MY, Park CJ, Cho YU, et al. Differences in PD-1 expression on CD8+ T-cells in chronic myeloid leukemia patients according to disease phase and TKI medication. Cancer immunology, immunotherapy : Cll 2020 doi: 10.1007/s00262-020-02617-5 [published Online First: 2020/06/01]

49. Di Giacomo AM, Valente M, Cerase A, et al. Immunotherapy of brain metastases: 
breaking a "dogma". Journal of Experimental \& Clinical Cancer Research 2019;38(1):419. doi: 10.1186/s13046-019-1426-2

50. Schmidberger $H$, Rapp $M$, Ebersberger $A$, et al. Long-term survival of patients after ipilimumab and hypofractionated brain radiotherapy for brain metastases of malignant melanoma: sequence matters. Strahlentherapie und Onkologie : Organ der Deutschen Rontgengesellschaft [et al] 2018;194(12):1144-51. doi: 10.1007/s00066-018-1356-5 [published Online First: 2018/10/10]

51. Kocher M, Ruge MI, Galldiks N, et al. Applications of radiomics and machine learning for radiotherapy of malignant brain tumors. Strahlentherapie und Onkologie 2020;196(10):856-67. doi: 10.1007/s00066-020-01626-8 
medRxiv preprint doi: https://doi.org/10.1101/2020.08.03.20167163; this version posted October 2, 2020. The copyright holder for this preprint (which was not certified by peer review) is the author/funder, who has granted medRxiv a license to display the preprint in perpetuity.

It is made available under a CC-BY-NC 4.0 International license .

\section{Figure legends}

Figure 1. Research design (A) and flowchart (B) for the identification of a predictive signature by immunophenotyping (IPT) for metastatic cancer patients treated with immune checkpoint inhibitors (ICI).

\section{Figure 2. Characteristics of the liquid immune profile-based signature (LIPS)} in the training and validation cohorts.

(A) The risk score of each metastatic cancer patient (patient ID) treated with immune checkpoint inhibitors (ICl) in the training cohort. (B) Overall survival and survival status of metastatic cancer patients in the training cohort. (C) Heat map of immune cell counts of metastatic cancer patients in the training cohort. (D) The risk score of each metastatic cancer patient treated with $\mathrm{ICl}$ in the validation cohort. (E) Overall survival and survival status of metastatic cancer patients in the validation cohort. (F) Heat map of immune cell counts of metastatic cancer patients in the validation cohort. pDCs: plasmacytoid dendritic cells; NKT cells: natural killer T cells; PD-1: Programmed cell death protein 1.

Figure 3. The ability of the LIPS to predict the overall survival in the training and validation cohorts.

(A) The overall survival in training cohort stratified by the LIPS into high- and low-risk with the $P$-value. (B) Time-dependent ROC curves of LIPS in the training cohort. (C) The overall survival in validation cohort stratified by the LIPS into high- and low-risk with the $P$-value. (D) Time-dependent ROC curves of LIPS in the validation cohort.

Figure 4. LIPS predicts survival benefit from ICI treatment in all metastatic cancer patients of the ST-ICl cohort.

(A) The overall survival in all patients stratified by the LIPS into high- and low-risk with the $P$-value. (B) Time-dependent ROC curves of LIPS for overall survival in all patients. (C) The progression-free survival in all patients stratified by the LIPS into high- and 
low-risk with the P-value. (D) Time-dependent ROC curves of LIPS for progression-free survival in all patients.

Figure 5. Subgroup analysis of the LIPS predict survival benefit of patients treated with ICI by baseline characteristics.

Subgroup analysis of the LIPS predict overall survival benefit (A) and progression-free survival benefit (B) of patients treated with ICI. Hazard Ratio and 95\% Confidence Intervals.

Table legends

Table 1. Baseline characteristics of metastatic cancer patients treated with ICI and for which immunophenotyping was performed before the second administration of ICI.

Table 2. Univariate Cox regression $(p<0.2)$.

Table 3 . Univariate and multivariate Cox regression analysis for overall survival and progression-free survival.

\section{Supplementary information}

sFigure 1. Schematic overview of the immune cell types identified in the immunophenotyping assay. The scheme depicts the immune cell subtypes analyzed from whole blood. The main cell types (big cells) are identified by their expression of specific cell surface molecules (pan markers). The defined cell types are excluded from the further gating steps, which allows the identification of cell types not expressing characteristic pan markers (dendritic cells, basophils). The main cell types are further divided in cell subtypes (small cells) by analyzing further surface 
medRxiv preprint doi: https://doi.org/10.1101/2020.08.03.20167163; this version posted October 2, 2020. The copyright holder for this preprint (which was not certified by peer review) is the author/funder, who has granted medRxiv a license to display the preprint in perpetuity.

It is made available under a CC-BY-NC 4.0 International license.

molecules. The immune cell types and subtypes are finally analyzed for the expression of various activation markers (CD25, CD69, CD80, CD86, PD-L1, HLA-DR, CTLA-4 and PD-1).

\section{sFigure 2. LIPS predict survival benefit from ICI by tumour entity.}

(A) The overall survival in HNSCC patients stratified by the LIPS into high- and low-risk with the $P$-value. (B) The overall survival in NSCLC patients stratified by the LIPS into high- and low-risk with the $P$-value. (C) The progression-free survival in HNSCC patients stratified by the LIPS into high- and low-risk with the $P$-value. (D) The progression-free survival in NSCLC patients stratified by the LIPS into high- and low-risk with the $P$-value.

\section{sFigure 3. LIPS predict survival benefit from ICI by PD-L1 expression.}

(A) The overall survival in patients with PD-L1 $<1 \%$ stratified by the LIPS into highand low-risk with the $P$-value. (B) The overall survival in patients with $1 \%<$ PD-L1 $<49 \%$ stratified by the LIPS into high- and low-risk with the $P$-value. (C) The overall survival in patients with PD-L1 $>50 \%$ stratified by the LIPS into high- and low-risk with the $P$-value. (D) The progression-free survival in patients with PD-L $1<1 \%$ stratified by the LIPS into high- and low-risk with the $P$-value. (E) The progression-free survival in patients with $1 \%<$ PD-L1 < 49\% stratified by the LIPS into high- and low-risk with the $P$-value. (F) The progression-free survival in patients with PD-L1 $>50 \%$ stratified by the LIPS into high- and low-risk with the $P$-value.

\section{sFigure 4. LIPS predict survival benefit from ICI by non-brain metastasis.}

(A) The overall survival in patients with brain metastasis stratified by the LIPS into high- and low-risk with the $P$-value. (B) The overall survival in patients without brain metastasis stratified by the LIPS into high- and low-risk with the $P$-value. (C) The progression-free survival in patients brain metastasis stratified by the LIPS into highand low-risk with the $P$-value. (D) The progression-free survival in patients without brain metastasis stratified by the LIPS into high- and low-risk with the $P$-value. 
medRxiv preprint doi: https://doi.org/10.1101/2020.08.03.20167163; this version posted October 2, 2020. The copyright holder for this preprint (which was not certified by peer review) is the author/funder, who has granted medRxiv a license to display the preprint in perpetuity.

\section{sFigure 5. LIPS predict survival benefit from ICI by age.}

(A) The overall survival in age $<60 \mathrm{yr}$ patients stratified by the LIPS into high- and low-risk with the $P$-value. (B) The overall survival in age $\geq 60 \mathrm{yr}$ patients stratified by the LIPS into high- and low-risk with the $P$-value. (C) The progression-free survival in age $<60 y$ r patients stratified by the LIPS into high- and low-risk with the $P$-value. (D) The progression-free survival in age $\geq 60 \mathrm{yr}$ patients stratified by the LIPS into highand low-risk with the $P$-value.

sFigure 6. LIPS predict survival benefit from ICI by gender.

(A) The overall survival in male patients stratified by the LIPS into high- and low-risk with the $P$-value. (B) The overall survival in female patients stratified by the LIPS into high- and low-risk with the $P$-value. (C) The progression-free survival in male patients stratified by the LIPS into high- and low-risk with the $P$-value. (D) The progression-free survival in female patients stratified by the LIPS into high- and low-risk with the $P$-value. 
medRxiv preprint doi: https://doi.org/10.1101/2020.08.03.20167163; this version posted October 2, 2020. The copyright holder for this preprint (which was not certified by peer review) is the author/funder, who has granted medRxiv a license to display the preprint in perpetuity.

Table 1. Baseline characteristics of metastatic cancer patients treated with $\mathrm{ICl}$ and for which immunophenotyping was performed before the second administration of ICI.

\begin{tabular}{llll}
\hline Features & Training cohort & Validation cohort & P-value \\
\hline $\begin{array}{l}\text { Total } \\
\text { Gender }\end{array}$ & 56 & 33 & \\
$\begin{array}{l}\text { Male } \\
\text { Female }\end{array}$ & $42(75 \%)$ & $23(69.7 \%)$ & \\
Age & $14(25 \%)$ & $10(30.3 \%)$ & \\
$>=60$ & & & 0.4133 \\
$<60$ & $16(28.57 \%)$ & $13(39.39 \%)$ & \\
Tumor entity & $40(71.43 \%)$ & $20(60.61 \%)$ & \\
HNSCC & & & 0.8186 \\
NSCLC & $24(42.86 \%)$ & $16(48.49 \%)$ & \\
others & $26(46.42 \%)$ & $13(39.39 \%)$ & \\
Brain metastasis & $6(10.71 \%)$ & $4(12.12 \%)$ & \\
Yes & & & \\
No & $12(21.43 \%)$ & $5(15.15 \%)$ & \\
PD-L1 expression & $44(78.57 \%)$ & $28(84.85 \%)$ & \\
$<1 \%$ & & & \\
$1-49 \%$ & $19(33.93 \%)$ & $12(36.37 \%)$ & \\
$50 \%-100 \%$ & $18(32.14 \%)$ & $10(30.3 \%)$ & \\
NA & $17(30.36 \%)$ & $11(33.33 \%)$ & \\
\hline
\end{tabular}


medRxiv preprint doi: https://doi.org/10.1101/2020.08.03.20167163; this version posted October 2, 2020. The copyright holder for this preprint (which was not certified by peer review) is the author/funder, who has granted medRxiv a license to display the preprint in perpetuity.

Table 2. Univariate Cox regression $(p<0.2)$.

\begin{tabular}{|c|c|c|c|}
\hline Characteristics & HR & $95 \% \mathrm{Cl}$ & P Value \\
\hline Monocytes (CD14 ${ }^{\text {high }}$ ) & 0.28 & $0.16-0.47$ & 0 \\
\hline Monocytes (CD14 low) & 1.37 & $1.14-1.66$ & 0.00109 \\
\hline Neutrophils & 1.68 & $1.15-2.44$ & 0.00682 \\
\hline DCs & 0.69 & $0.47-1.03$ & 0.06665 \\
\hline mDCs-1 & 0.47 & $0.27-0.83$ & 0.00991 \\
\hline mDCs-2 & 0.75 & $0.58-0.97$ & 0.0258 \\
\hline pDCs & 0.56 & $0.4-0.8$ & 0.00114 \\
\hline NK cells (CD56 ${ }^{\text {high }} /$ CD16 ${ }^{+}$) & 0.84 & $0.64-1.09$ & 0.19433 \\
\hline NKT cells (CD56+/CD16 ${ }^{+}$) & 0.61 & $0.4-0.92$ & 0.01906 \\
\hline NKT cells (CD16 $\left.{ }^{+}\right)$ & 0.76 & $0.58-1$ & 0.0491 \\
\hline CD8+ T cells (PD-1+) & 1.63 & $1.06-2.51$ & 0.02604 \\
\hline CD8+ T cells (CD25+) & 1.2 & $0.93-1.56$ & 0.1591 \\
\hline CD8+ T cells (CD69+) & 0.75 & $0.49-1.15$ & 0.18642 \\
\hline$T_{\text {regs }}$ & 0.79 & $0.58-1.08$ & 0.14495 \\
\hline
\end{tabular}


Table 3. Univariate and multivariate Cox regression analysis for overall survival and progression-free survival.

\begin{tabular}{|c|c|c|c|c|c|c|c|c|c|c|c|c|}
\hline \multirow[b]{3}{*}{ Parameter } & \multicolumn{6}{|c|}{ Overall Survival } & \multicolumn{6}{|c|}{ Progression-Free Survival } \\
\hline & \multicolumn{3}{|c|}{ univariate Cox regression } & \multicolumn{3}{|c|}{ multivariate regression } & \multicolumn{3}{|c|}{ univariate regression } & \multicolumn{3}{|c|}{ multivariate regression } \\
\hline & HR & $95 \% \mathrm{Cl}$ & $P$ & HR & $95 \% \mathrm{Cl}$ & $P$ & HR & $95 \% \mathrm{Cl}$ & $P$ & HR & $95 \% \mathrm{Cl}$ & $P$ \\
\hline \multicolumn{13}{|c|}{ LIPS signature } \\
\hline High risk & Ref & & & Ref & & & Ref & & & Ref & & \\
\hline Low risk & 0.28 & $0.15-0.52$ & $<0.001^{* * *}$ & 0.27 & $0.12-0.57$ & $<0.001^{* * *}$ & 0.22 & $0.12-0.39$ & $<0.001^{* * *}$ & 0.23 & $0.10-0.52$ & $<0.001^{* * *}$ \\
\hline \multicolumn{13}{|l|}{ Age } \\
\hline$<60 \mathrm{yr}$ & Ref & & & Ref & & & Ref & & & Ref & & \\
\hline$\geq 60 \mathrm{yr}$ & 1.36 & $0.77-2.41$ & 0.3 & 2.22 & $1.12-4.41$ & $0.023^{*}$ & 1.13 & $0.68-1.86$ & 0.6 & 1.56 & $0.89-2.75$ & 0.12 \\
\hline \multicolumn{13}{|l|}{ Gender } \\
\hline Male & Ref & & & Ref & & & Ref & & & Ref & & \\
\hline Female & 1 & $0.54-1.86$ & 1 & 1.46 & $0.68-3.09$ & 0.323 & 0.77 & $0.44-1.34$ & 0.4 & 0.98 & $0.52-1.86$ & 0.95 \\
\hline \multicolumn{13}{|c|}{ Tumour entity } \\
\hline Others & Ref & & & Ref & & & Ref & & & Ref & & \\
\hline HNSCC & 0.91 & $0.54-1.55$ & 0.7 & 0.54 & $0.23-1.31$ & 0.172 & 1.41 & $0.88-2.25$ & 0.1 & 0.81 & $0.34-1.88$ & 0.618 \\
\hline NSCLC & 0.94 & $0.56-1.59$ & 0.8 & 0.6 & $0.25-1.46$ & 0.263 & 0.7 & $0.44-1.12$ & 0.1 & 0.56 & $0.23-1.38$ & 0.208 \\
\hline \multicolumn{13}{|c|}{ Brain metastasis } \\
\hline Yes & Ref & & & Ref & & & Ref & & & Ref & & \\
\hline No & 0.43 & $0.24-0.79$ & $0.005^{\star *}$ & 0.52 & $0.25-1.1$ & 0.087 & 0.46 & $0.26-0.80$ & $0.005^{\star \star}$ & 0.75 & $0.34-1.66$ & 0.481 \\
\hline \multicolumn{13}{|c|}{ PD-L1 expression } \\
\hline$<1 \% / N A$ & Ref & & & Ref & & & Ref & & & Ref & & \\
\hline $1-49 \%$ & 0.69 & $0.39-1.24$ & 0.2 & 0.57 & $0.30-1.12$ & 0.106 & 0.61 & $0.36-1.02$ & 0.06 & 0.51 & $0.27-0.96$ & $0.036^{*}$ \\
\hline $50-100 \%$ & 0.78 & $0.43-1.41$ & 0.4 & 0.44 & $0.20-0.93$ & $0.031^{*}$ & 0.89 & $0.54-1.47$ & 0.6 & 0.61 & $0.31-1.18$ & 0.142 \\
\hline
\end{tabular}

Note: ${ }^{*} p<0.05,{ }^{* *} p<0.01,{ }^{* * *} p<0.001$ 
A

First Second

administration administration

$\mathrm{ICl}$

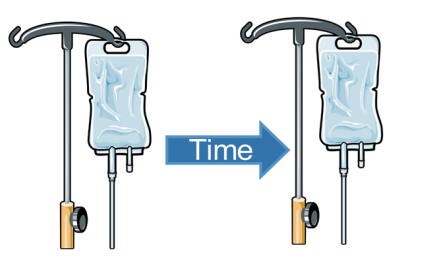

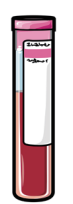

Whole blood time point 2
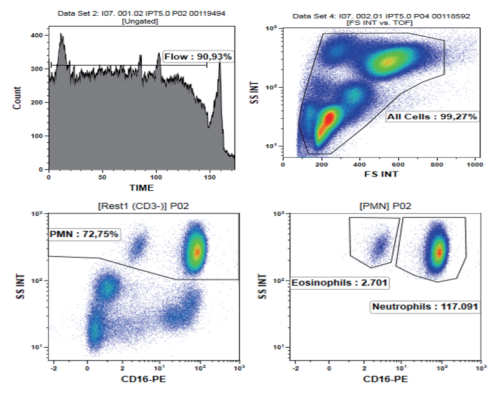

Multi-parameter Flow Cytometry
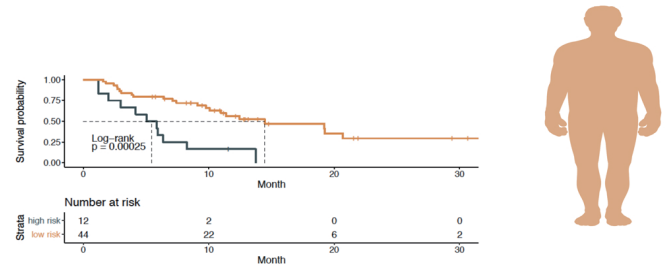

Patients with benefit from $\mathrm{ICl}$
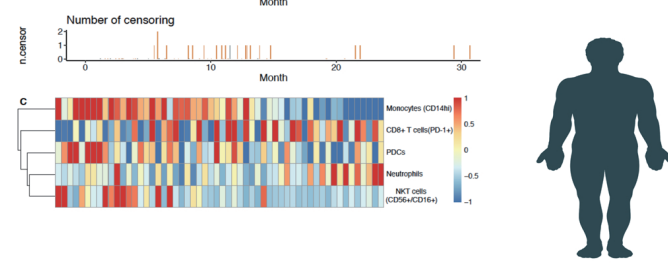

Patients without benefit from $\mathrm{ICl}$

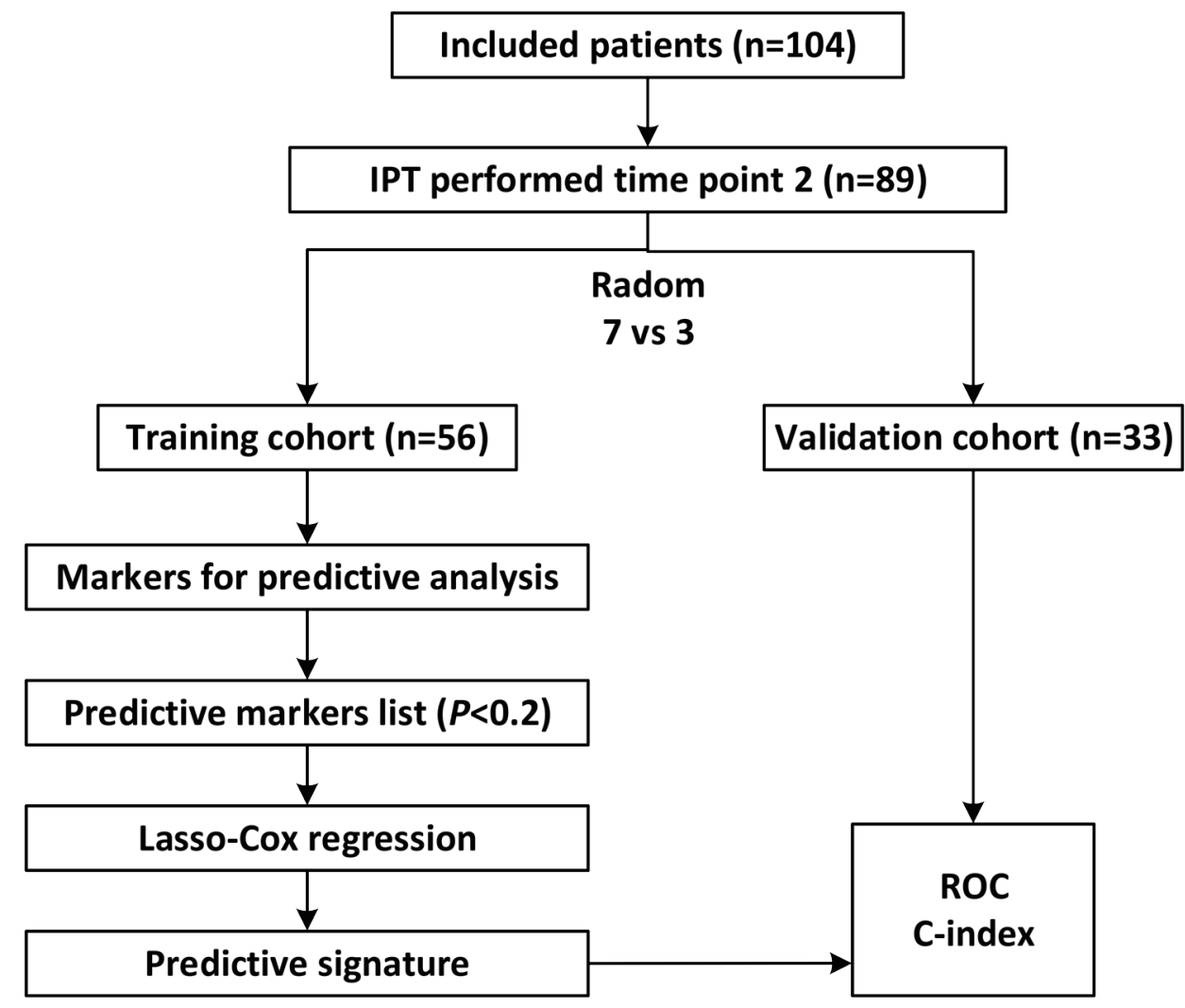



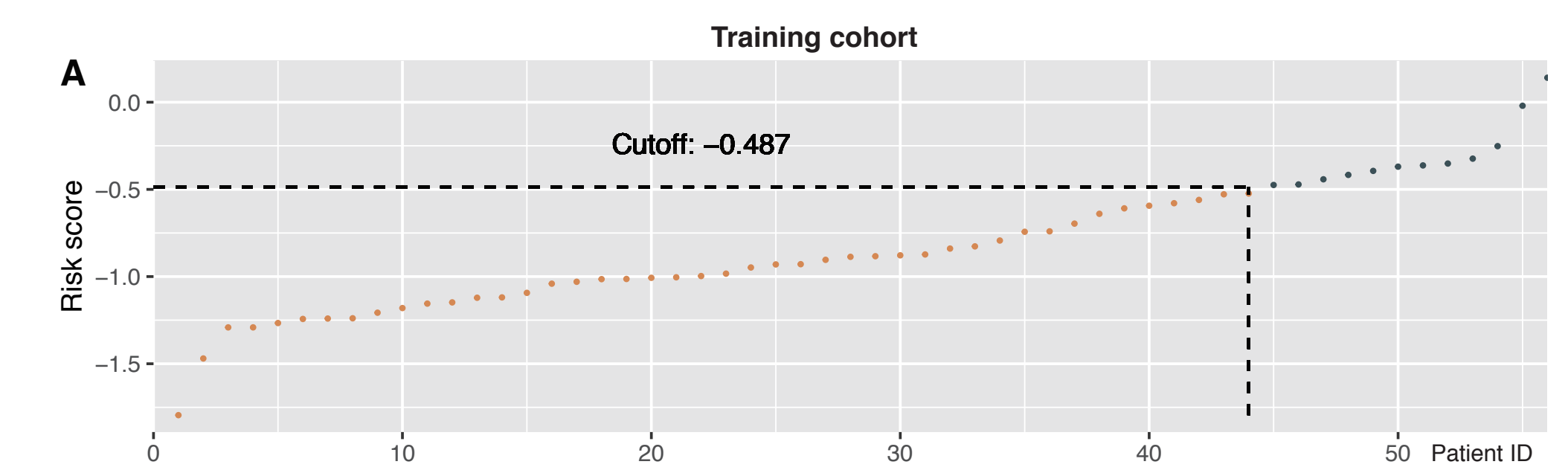

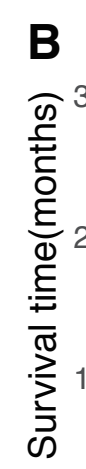

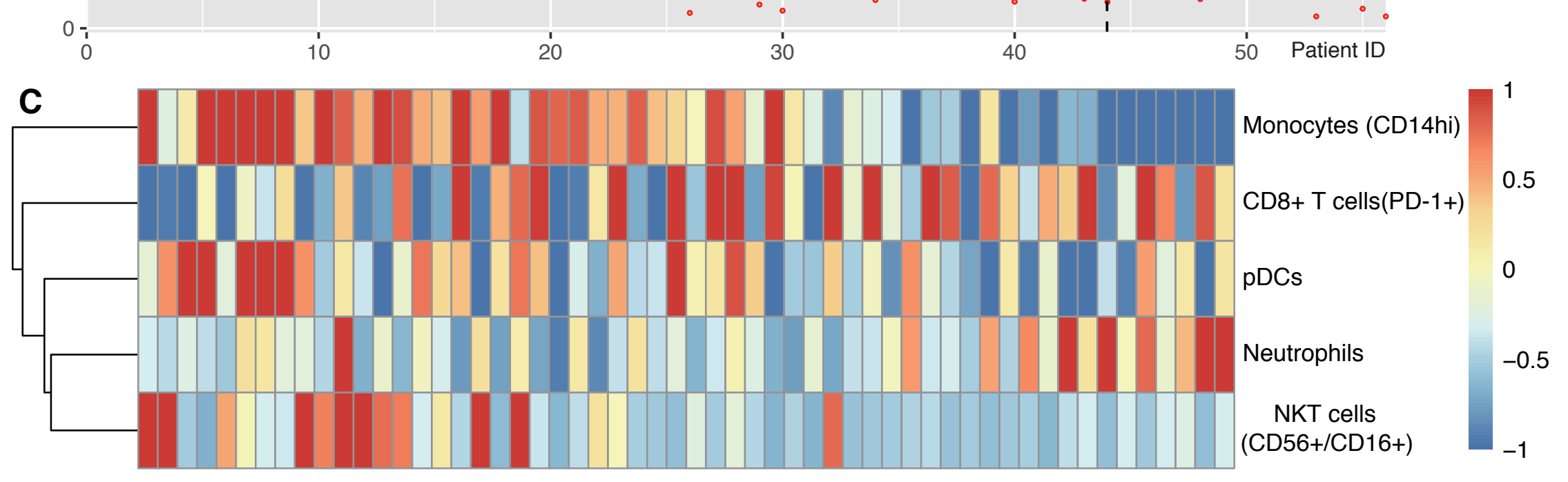

Risk

- high

- low

D

Validation cohort

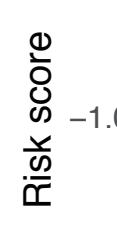

Risk

- high

- low

Patient ID

Status

Status

$\begin{array}{ll}\text { - } & \text { alive } \\ \text { - death }\end{array}$

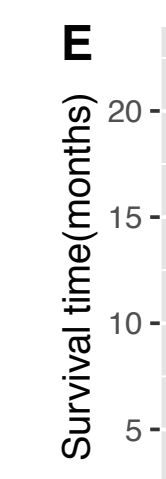

10

20

- alive
- death

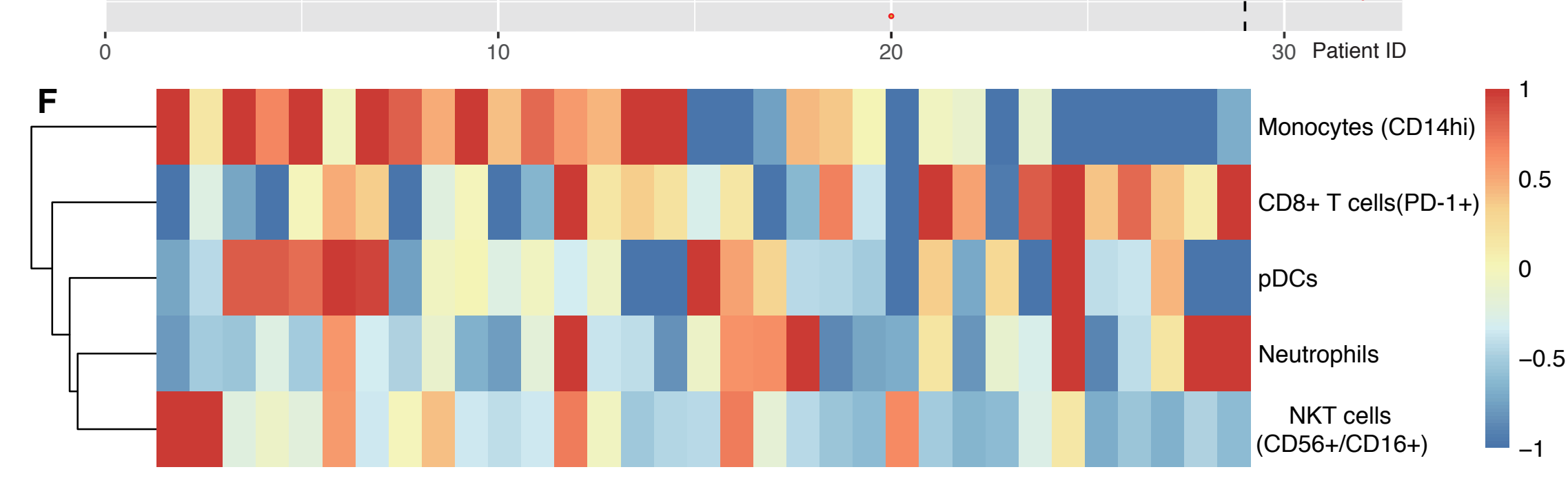




\section{A Training cohort OS}

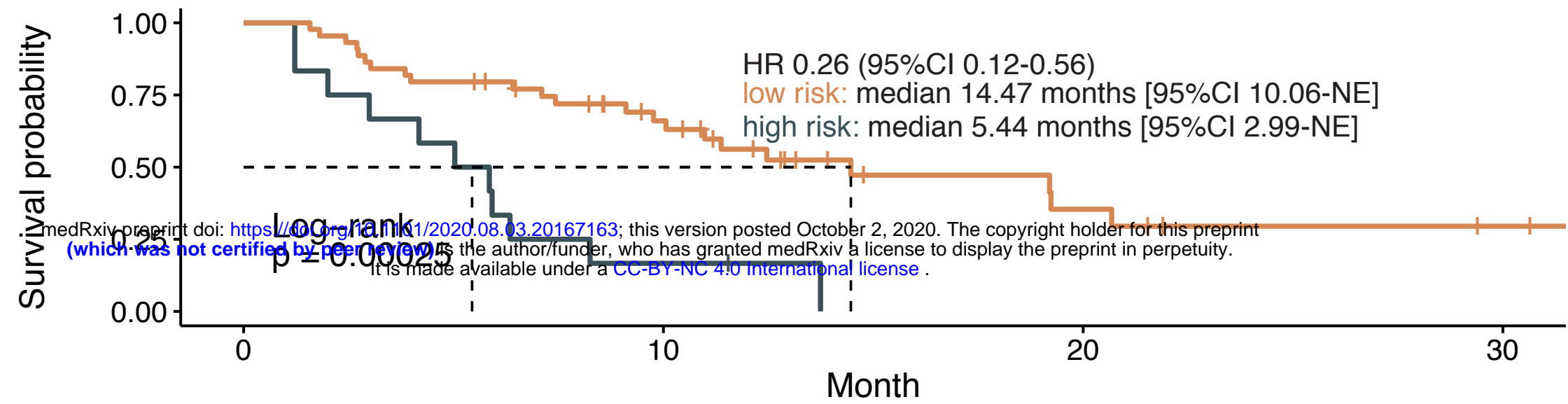

Number at risk

\begin{tabular}{|c|c|c|c|c|}
\hline \multirow{3}{*}{ 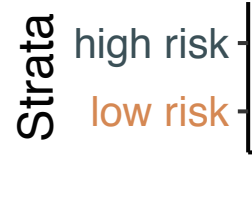 } & 12 & 2 & 0 & 0 \\
\hline & 44 & 22 & 6 & 2 \\
\hline & 0 & 10 & 20 & 30 \\
\hline
\end{tabular}

Number of censoring

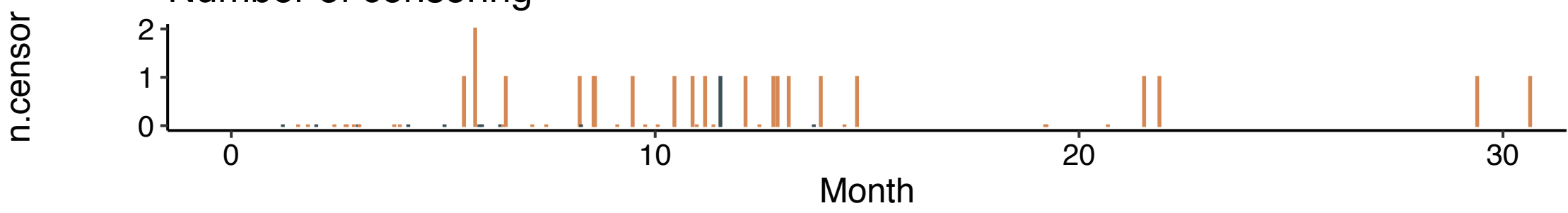

\section{Validation cohort OS}

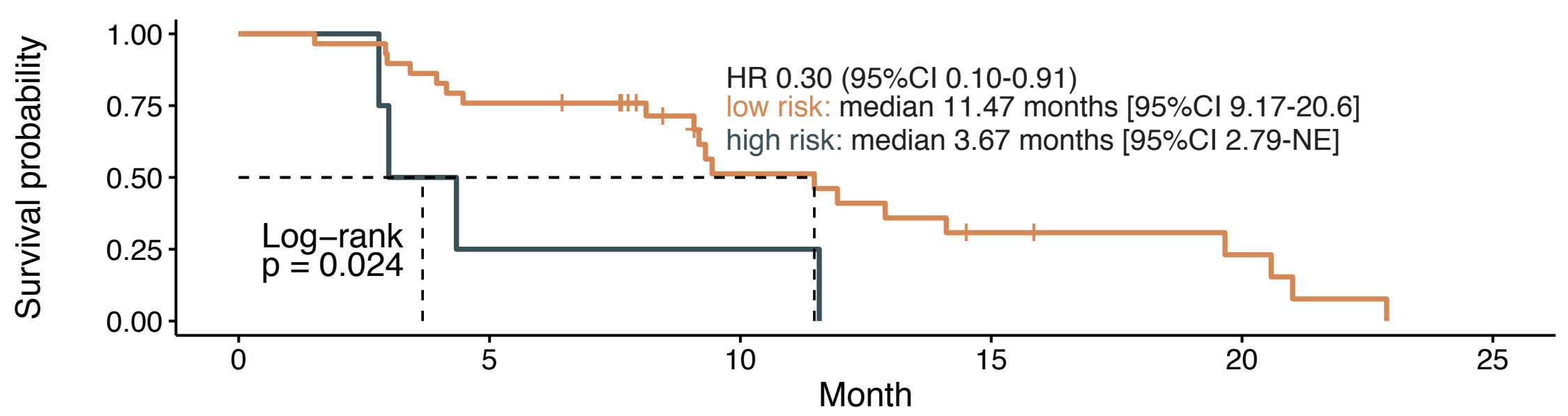

Number at risk

\begin{tabular}{|c|c|c|c|c|c|c|}
\hline \multirow{3}{*}{ 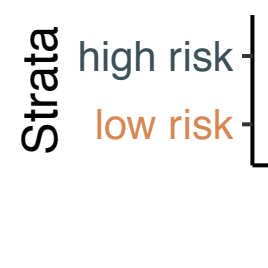 } & 4 & 1 & 1 & 0 & 0 & 0 \\
\hline & 29 & 22 & 10 & 5 & 3 & 0 \\
\hline & 0 & 5 & 10 & $\frac{1}{15}$ & 20 & 25 \\
\hline
\end{tabular}

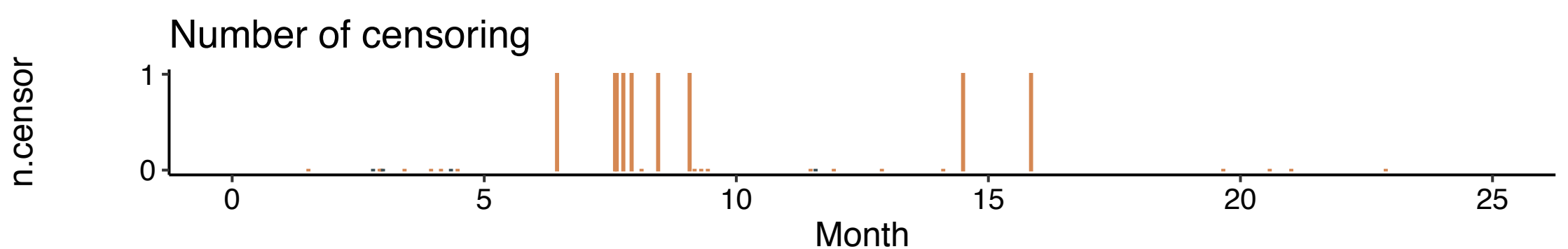

\section{B Training cohort ROC}

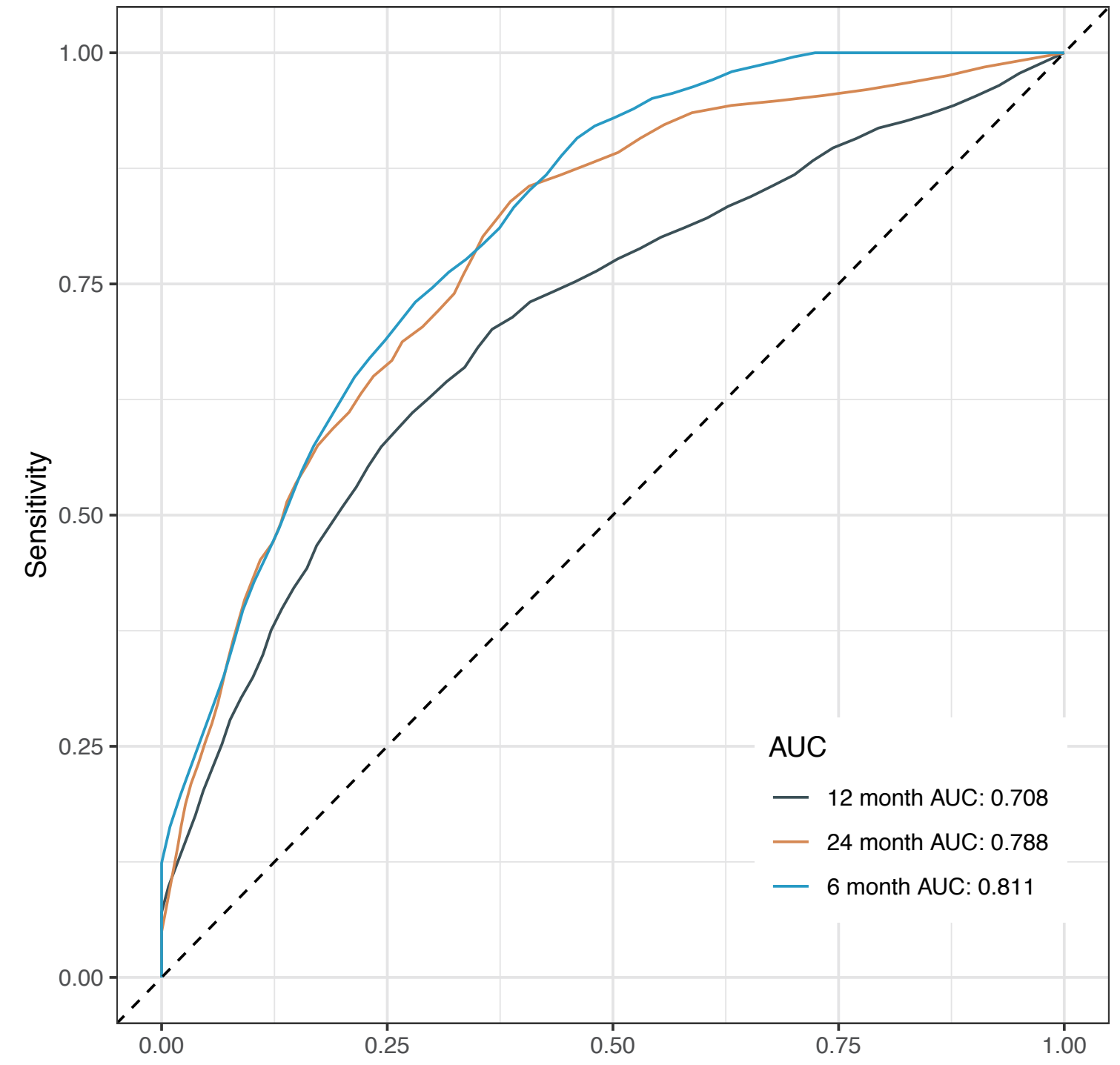

D Validation cohort ROC

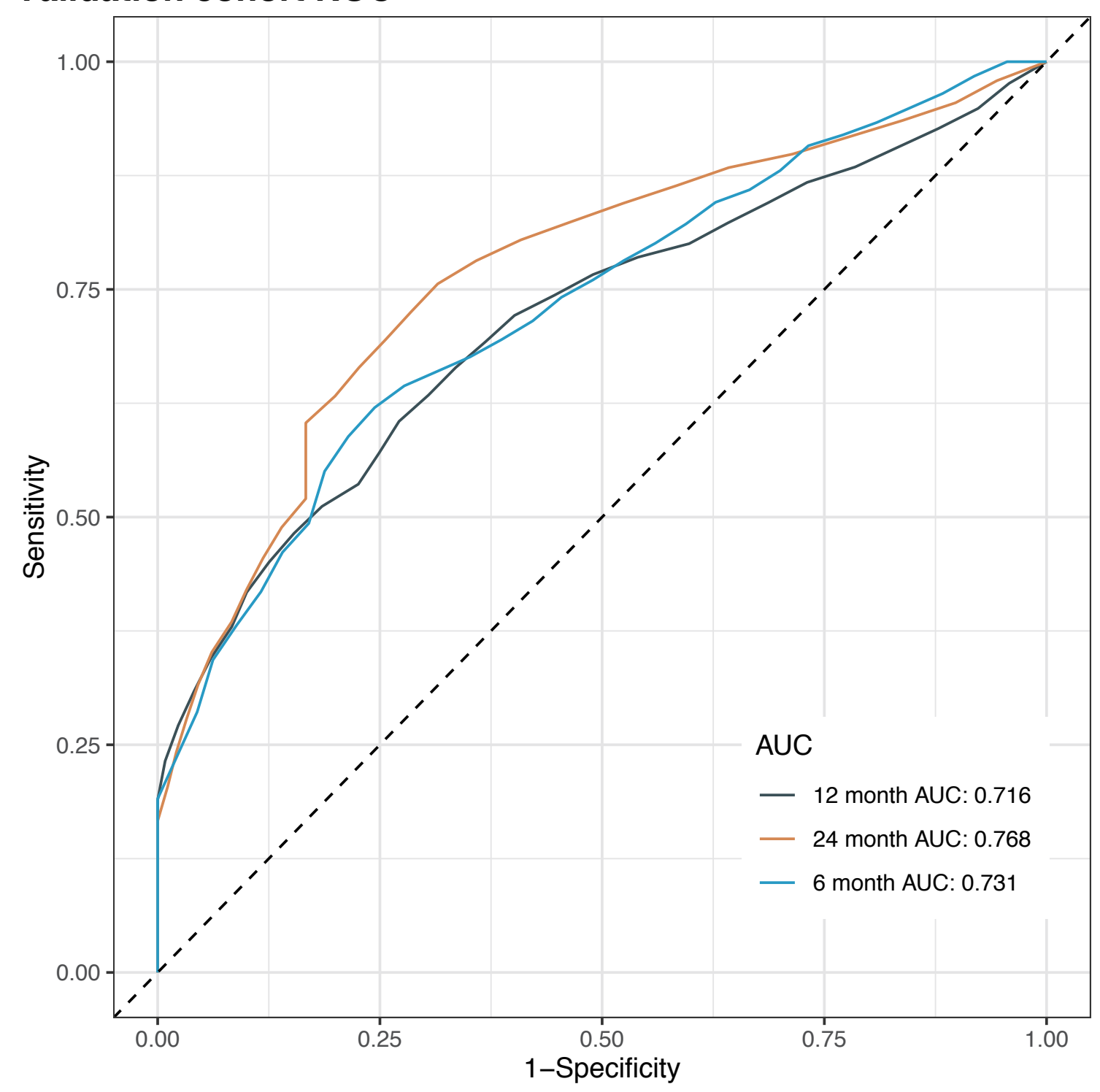




\section{A ST-ICl cohort OS}

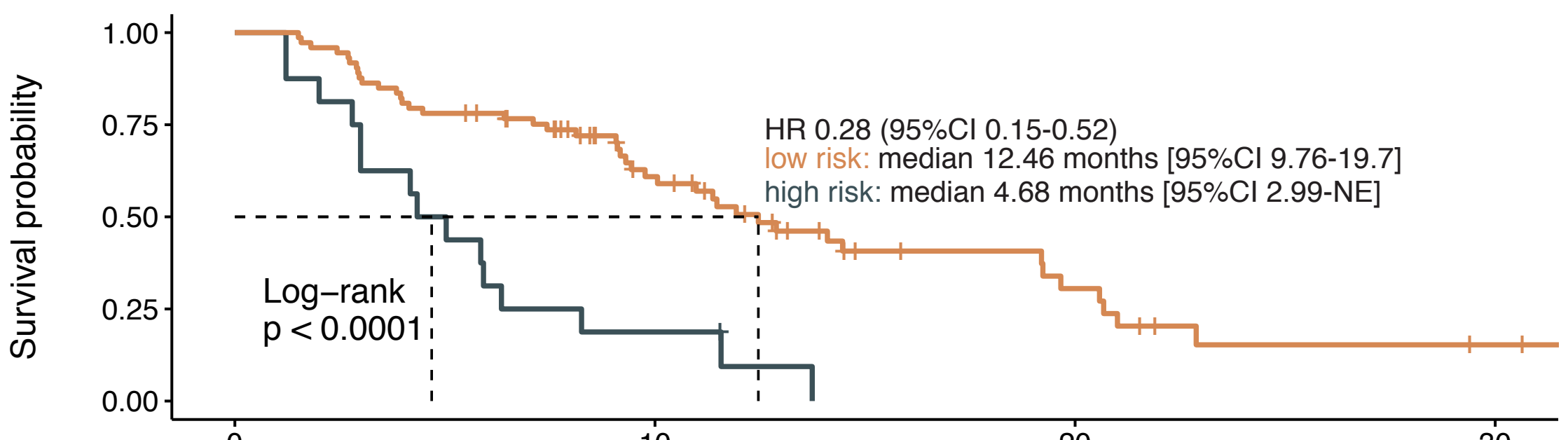

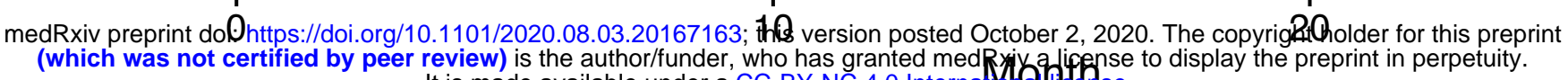

30

Number at risk

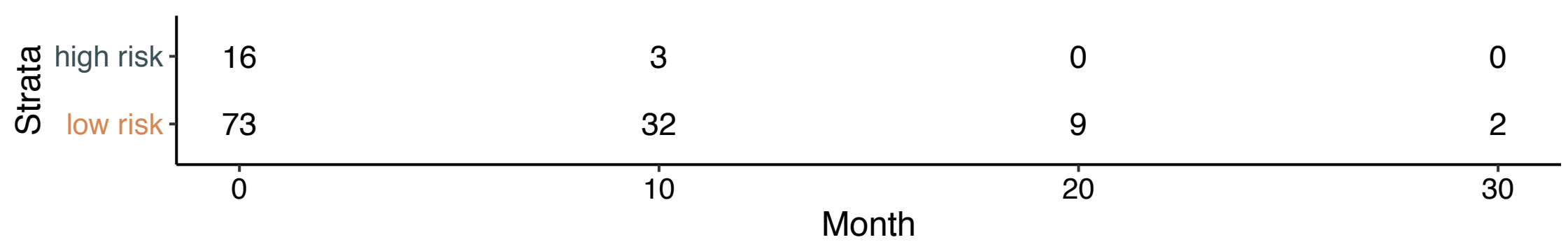

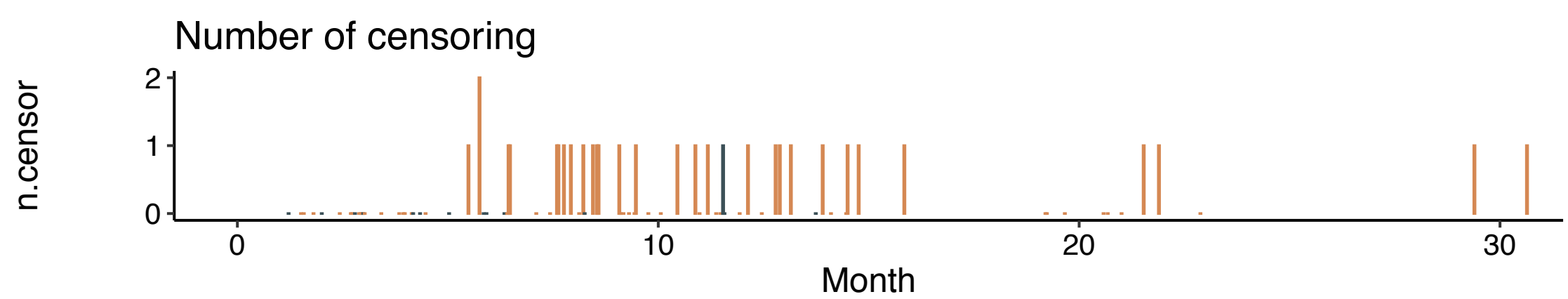

\section{ST-ICI cohort PFS}

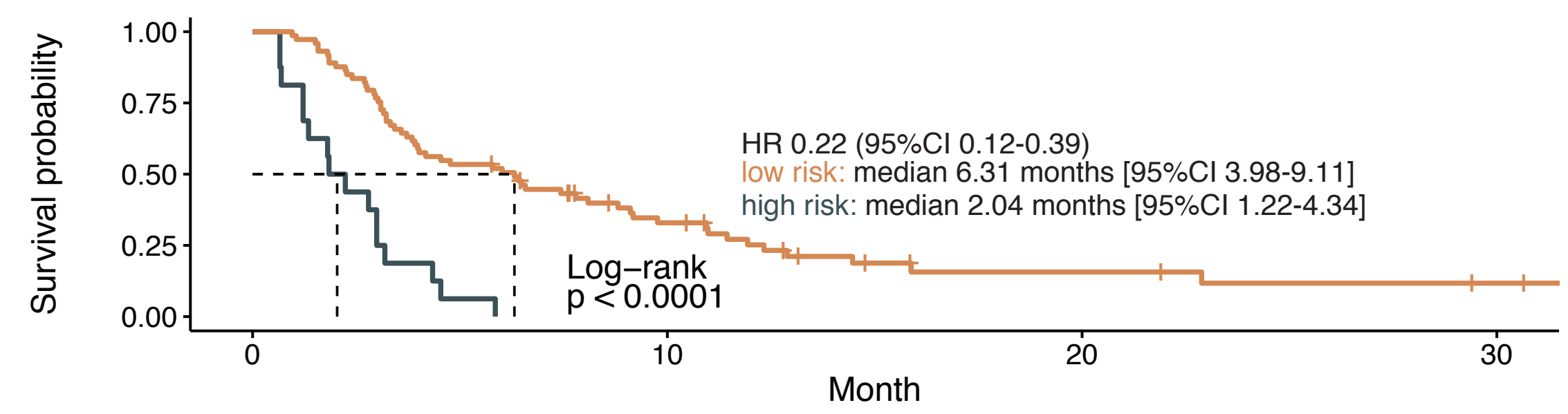

Number at risk

\begin{tabular}{|c|c|c|c|c|}
\hline \multirow{3}{*}{ 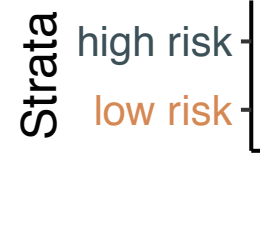 } & 16 & 0 & 0 & 0 \\
\hline & 73 & 19 & 5 & 2 \\
\hline & 0 & 10 & 20 & 30 \\
\hline
\end{tabular}

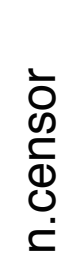

Number of censoring

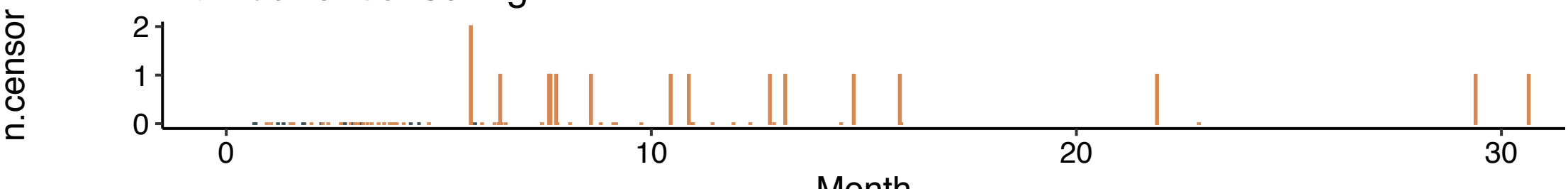

B ST-ICI cohort OS ROC

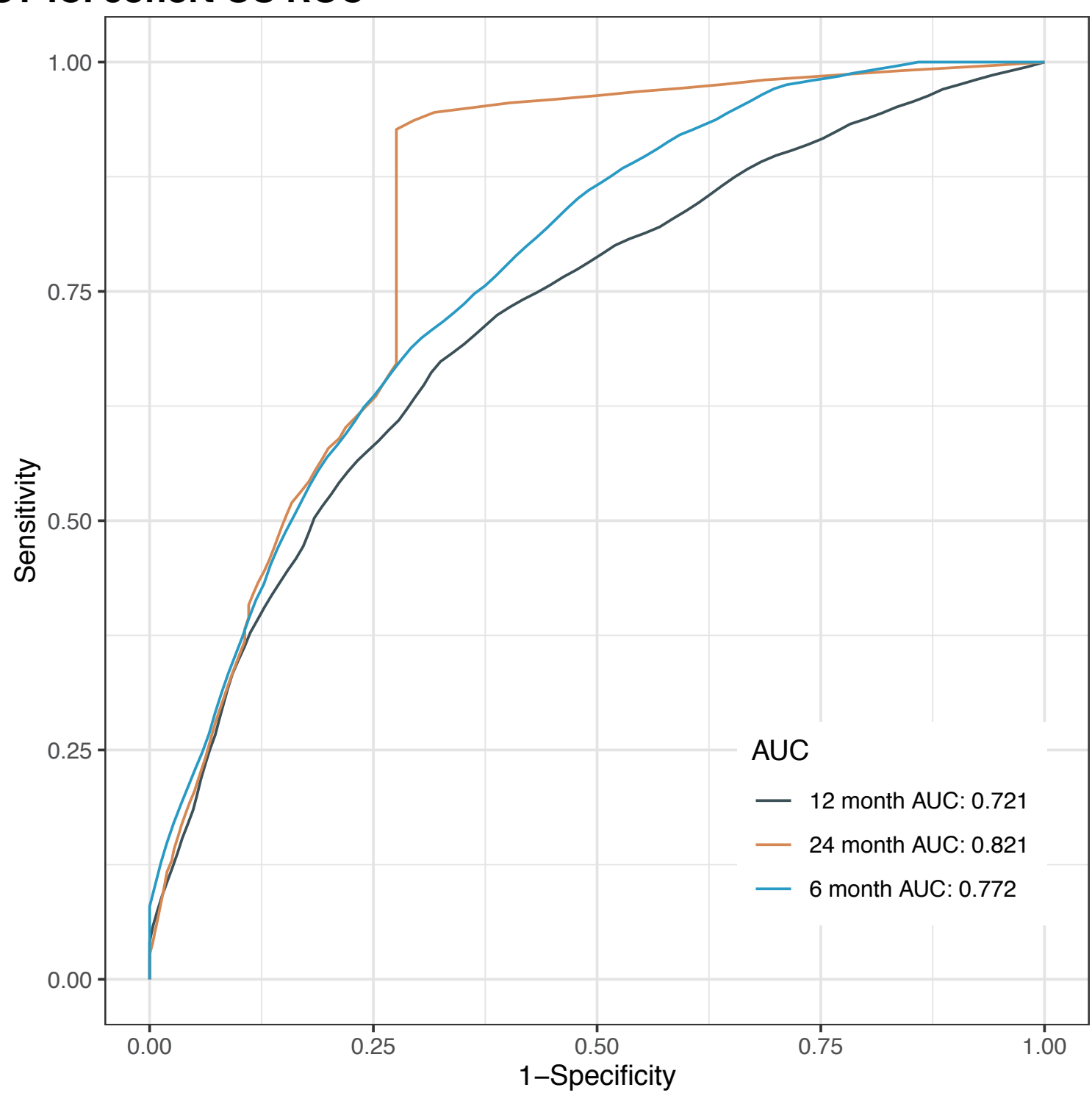

D ST-ICI cohort PFS ROC

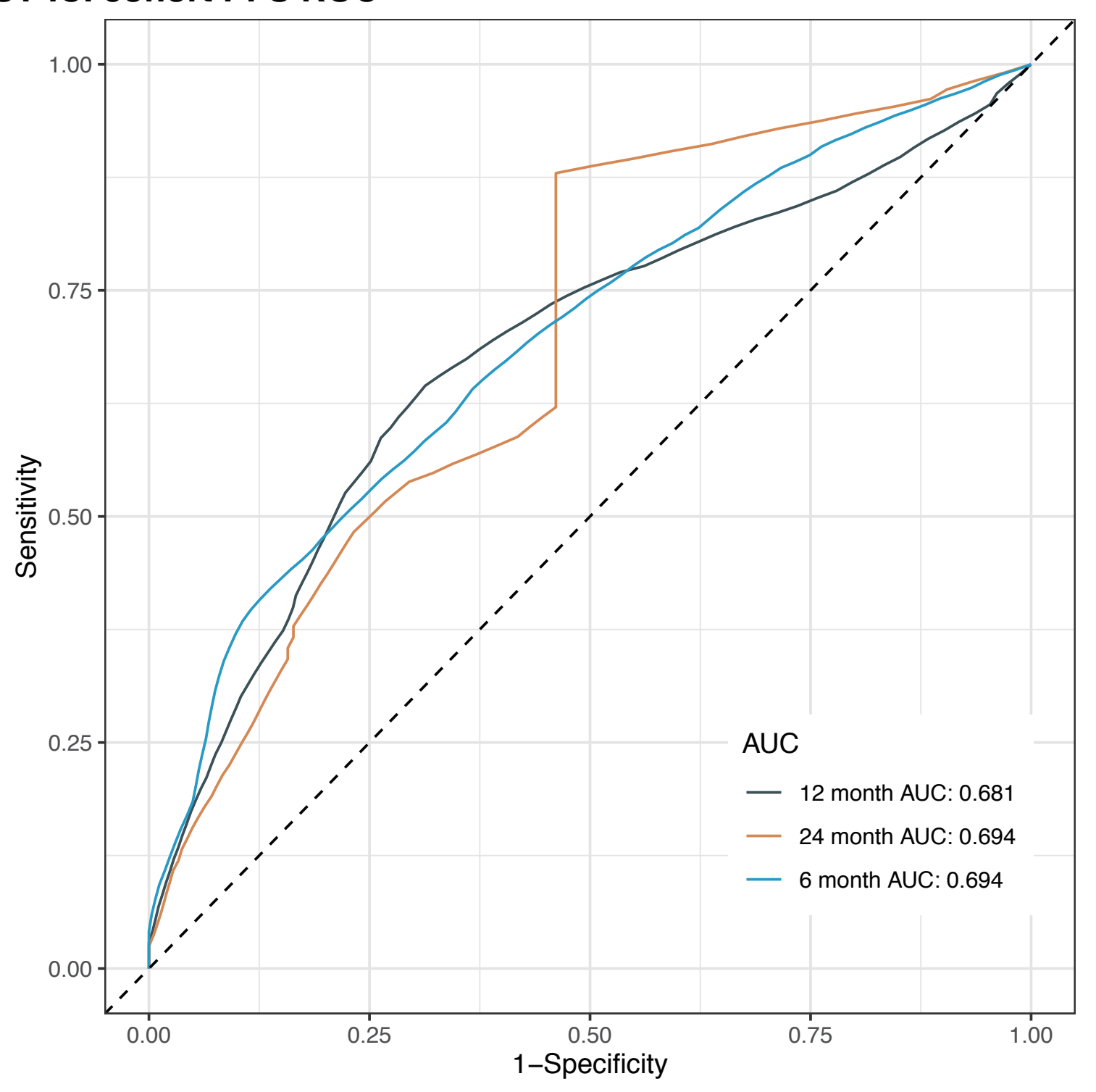




\section{A. Subgroup analysis of OS}

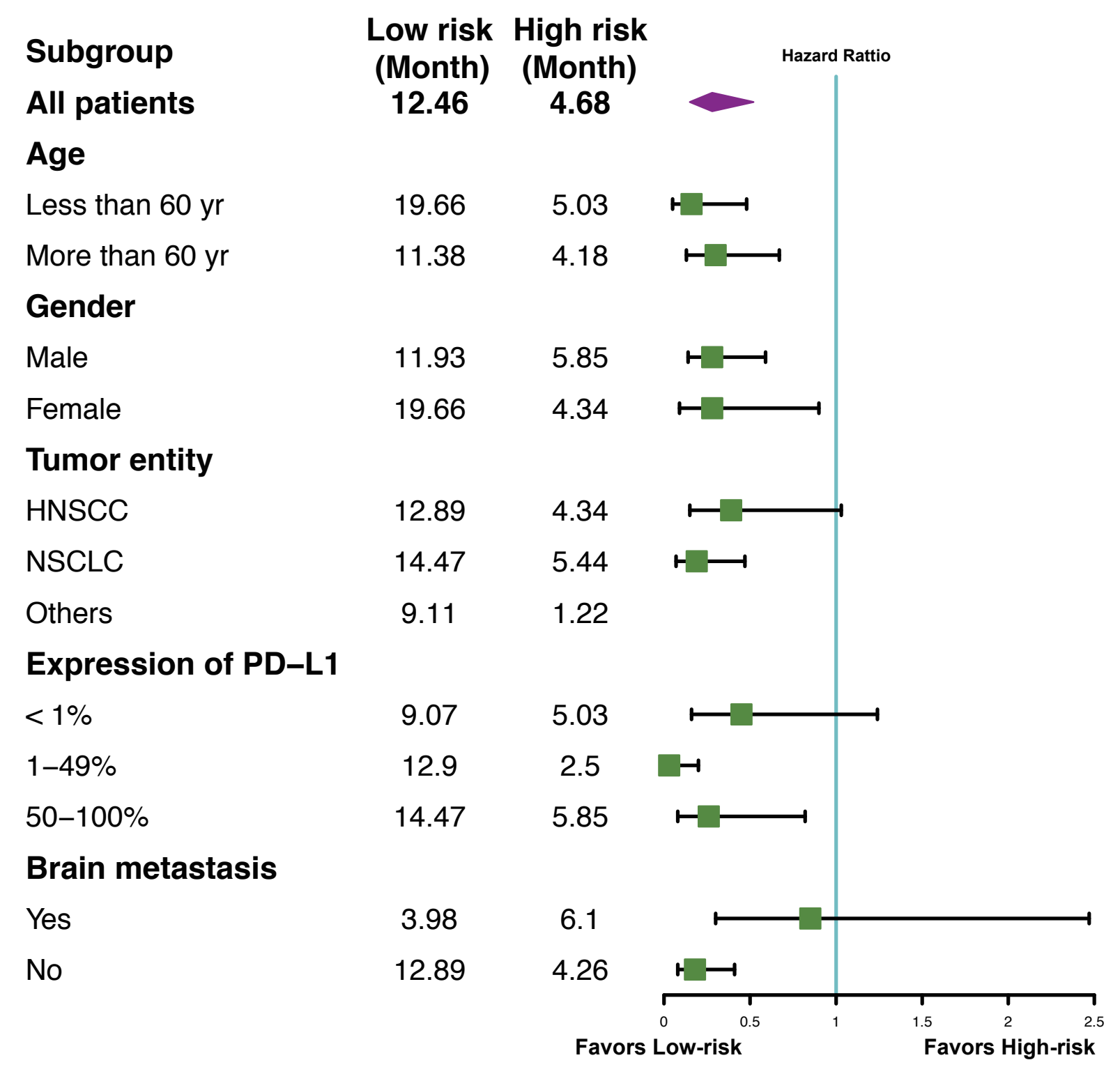

\section{B. Subgroup analysis of PFS}

\section{Hazard Ratio \\ $(95 \% \mathrm{Cl})$}

$0.28(0.15-0.52)$

$0.16(0.05-0.48)$

$0.30(0.13-0.67)$

$0.28(0.14-0.59)$

$0.28(0.09-0.90)$

$0.39(0.15-1.03)$

$0.19(0.07-0.47)$

$2.788 \mathrm{e}-10(0-\operatorname{lnf})$

$0.45(0.16-1.24)$

$0.03(0.01-0.20)$

$0.26(0.08-0.82)$

$0.85(0.30-2.47)$

$0.18(0.08-0.41)$
Subgroup
All patients

Age

Less than $60 \mathrm{yr}$

More than $60 \mathrm{yr}$

Gender

Male

Female

Tumor entity

HNSCC

NSCLC

Others

Expression of PD-L1

$<1 \%$

$1-49 \%$

50-100\%

Brain metastasis

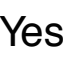

No
Low risk High risk

$\begin{array}{cc}\text { (Month) } & \text { (Month) } \\ 6.31 & 2.04\end{array}$

6.31

7.43

$$
6.02
$$

2.99

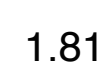

5.79

9.76

2.24

1.84

$\begin{array}{ll}3.91 & 2.99\end{array}$

$8.81 \quad 2.04$

$3.42 \quad 1.22$

3.5

9.1

1.81

0.94

2.79

ar

$\mapsto$

2.4

6.58

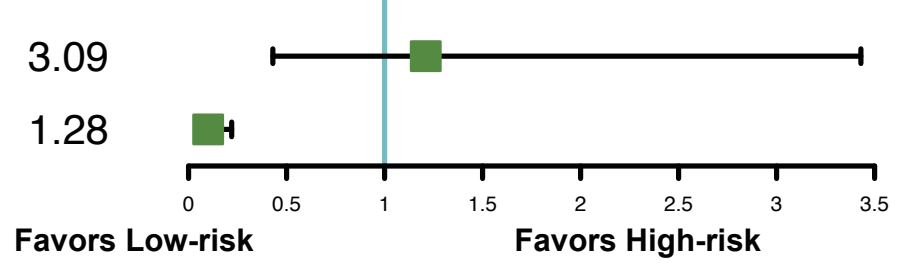

Hazard Ratio

(95\% Cl)

$0.22(0.12-0.39)$

$0.25(0.09-0.68)$

$0.17(0.08-0.37)$

$0.22(0.11-0.44)$

$0.22(0.07-0.70)$

$0.34(0.14-0.82)$

$0.12(0.05-0.32)$

$7.578 \mathrm{e}-10$ (0-Inf)

$0.34(0.12-0.94)$

$0.05(0.01-0.23)$

$0.22(0.08-0.61)$

$1.21(0.43-3.43)$

$0.10(0.05-0.22)$ 